\title{
Heterogeneity of Astrocyte Resting Membrane Potentials and Intercellular Coupling Revealed by Whole-Cell and Gramicidin- Perforated Patch Recordings from Cultured Neocortical and Hippocampal Slice Astrocytes
}

\author{
Guy M. McKhann II,' ${ }^{1}$ Raimondo D’Ambrosio, ${ }^{1}$ and Damir Janigro ${ }^{1,2}$ \\ ${ }^{1}$ Departments of Neurological Surgery and ${ }^{2}$ Environmental Health, University of Washington School of Medicine, \\ Seattle, Washington 98104
}

\begin{abstract}
Astrocytes are thought to regulate the extracellular potassium concentration by mechanisms involving both voltage-dependent and transport-mediated ion fluxes combined with intercellular communication via gap junctions. Mechanisms regulating resting membrane potential (RMP) play a fundamental role in determining glial contribution to buffering of extracellular potassium and uptake of potentially toxic neurotransmitters. We have investigated the passive electrophysiological properties of cultured neocortical astrocytes and astrocytes recorded in hippocampal slices from $18-25 \mathrm{~d}$ postnatal rats. These experiments revealed a wide range of astrocyte RMPs that were independent of developmental factors, length of culturing, cellular morphology, the electrophysiological techniques used (whole-cell vs perforated recording), cell-specific expression of $\mathrm{Na}^{+} / 2 \mathrm{HCO}_{3}^{-}$co-transporters, or voltage-dependent $\mathrm{Na}^{+}$channels. Exposure of cultured astrocytes to differentiation-inducing factors (such as CAMP) or inhibition of proliferation (by serum deprivation) did not significantly
\end{abstract}

influence RMP. Expression of ATP-sensitive potassium channels was absent in these glia; thus, $\mathrm{K}_{\text {(ATP) }}$-related mechanisms did not contribute to cell resting potential. In both cultured and slice astrocytes, spontaneous electrophysiological changes were commonly observed. These reversible events, which resulted in differential sensitivity to potassium channel blockers (cesium and barium) and sudden current-voltage profile changes, were attributable to dynamic changes in cell-to-cell coupling, as confirmed by recordings from isolated pairs of cells. We conclude that the heterogeneity of astrocytic RMP and intercellular coupling both in culture and in situ are intrinsic properties of glia that may contribute to transcellular transport of potassium. We propose a model in which spatial buffering may be facilitated by heterogeneous mechanisms controlling glial RMP in combination with dynamic changes in intercellular coupling.

Key words: spatial buffering; ion channel; excitability; inward rectifier; glia/neuronal interactions; resting membrane potential
Astrocytes have traditionally been described as a relatively uniform population of cells characterized by a highly negative resting membrane potential (RMP), low input resistance, and extensive intercellular coupling via gap junctions (Kuffler et al., 1966; Ballanyi et al., 1987; Casullo and Krnjevic, 1987; Dermietzel et al., 1991; Giaume et al., 1991). Because of this intercellular communication network and the ubiquitous expression of large and predominant $I_{\mathrm{K}}$, astrocytes have often been modeled as a homogenous syncytium of coupled cells (Joyner and Somjen, 1973) adapted for the uptake of potassium in response to neuronal activity. In addition to removing excess $\left[\mathrm{K}^{+}\right]_{\text {out }}$, astrocytes can potentially transport potassium from areas of accumulation to regions where potassium is low or to the proximity of capillaries (Paulson and Newman, 1987). From a purely theoretical standpoint, the coexistence of rapid transmembrane transport together with a syncytium adapted for topographic regulation of $\left[\mathrm{K}^{+}\right]_{\text {out }}$ constitutes an ideal mechanism for potassium homeostasis. Direct

\footnotetext{
Received May 15, 1997; revised June 23, 1997; accepted June 26, 1997.

This manuscript was supported by Grants NS10217-01 (G.M.M.) and 51614 (D.J.) from the National Institutes of Health, Grant ES 07033 from the National Institute of Environmental Health Sciences (D.J.), and National Institutes of Health Grant NS 21076 (D.J.), and by the Research Foundation of the American Association of Neurological Surgeons (G.M.M.). We acknowledge Kathe A. Stanness for help with the tissue culture and Philip A. Schwartzkroin for helpful comments on this manuscript.

Correspondence should be addressed to Damir Janigro, Department of Neurological Surgery, 325 9th Avenue, Box 359914, Seattle, WA 98104.

Copyright (C) 1997 Society for Neuroscience $0270-6474 / 97 / 176850-14 \$ 05.00 / 0$
}

evidence for such a mechanism in the mammalian cortex has yet to be found.

Physiological investigations have revealed that astrocytes are not homogeneous (Black et al., 1993; Sontheimer, 1994; Guatteo et al., 1996). Astrocytes from different areas of the CNS express different ion channels and neurotransmitter receptors (Steinhauser, 1993; Sontheimer, 1994). Furthermore, astrocytes cultured from different regions display different levels of intercellular coupling (Lee et al., 1994). Both gap junction and ion channel expression are developmentally regulated (Sontheimer et al., 1992; Kressin et al., 1995; Giaume and McCarthy, 1996).

Despite the observed electrophysiological heterogeneity of astrocytes, it is assumed that these CNS glia are uniform with respect to RMP. This is perhaps surprising, given the variability in current expression reported for glia. Intracellular recording studies have identified astrocytes by criteria that include highly negative RMP and lack of "active" responses (Kuffler, 1967; Sontheimer and Waxman, 1993). This criterion has been established since the pioneering work by Nicholls and Kuffler (1964), who reported a mean RMP of $-67 \mathrm{mV}$. Assuming that astrocytic currents were exclusively permeant to potassium, recordings from putative glia ("unresponsive cells") with RMPs positive to $-60 \mathrm{mV}$ were discarded because these "sharp" electrode penetrations were thought to represent recordings from cell processes or injured cells. Because of sharp electrode technical limitations, it was impossible to determine whether a depolarized cell was healthy (e.g., Alger et al., 
1983). Kuffler and colleagues (1966) subsequently excluded all glial cells with RMP positive to $-85 \mathrm{mV}$.

The advent of patch clamping greatly improved the control of the electrophysiological properties of these glia; thus, $I_{\mathrm{Na}}$ expression became apparent, and subsets of potassium and mixed cation currents have been reproducibly recorded (Sontheimer, 1994). Nevertheless, the axiom of highly negative glial RMP established during the sharp microelectrode era has survived largely undisturbed through almost two decades of patch-clamp investigations.

Considering the importance that glial RMP and intercellular coupling have in modulating neuronal physiology, we studied the mechanisms involved in the regulation of astrocyte RMP. We found that astrocytes have a wide range of RMP and are dynamically coupled; these changes in cell-to-cell coupling impact the electrophysiological and pharmacological behavior of a given cell.

\section{MATERIALS AND METHODS}

All the experiments involving animals were performed in accordance with the guidelines for maintenance and care as put forth by the National Institutes for Health. The protocols for primary cell cultures and hippocampal slice preparation were approved by the University of Washington Animal Care Committee.

Cortical astrocyte cultures. Pregnant rats were anesthetized with halothane and decapitated. Primary cultures of rat astrocytes were obtained as described previously (Guatteo et al., 1996). Briefly, 21-d-old rat fetuses were removed from the uterus, and the heads were separated and immersed in cold HBSS without $\mathrm{Ca}^{2+}$ or $\mathrm{Mg}^{2+}$ (BioWhittaker, Walkersville, MD). Neocortices were isolated from the brain and subsequently minced in HBSS. After trituration the tissue was incubated for $15 \mathrm{~min}$ at $37^{\circ} \mathrm{C}$ in trypsin-versene mixture (BioWhittaker) containing trypsin $(0.5 \mu \mathrm{g} / \mathrm{ml})$ and EDTA $(0.2 \mu \mathrm{g} / \mathrm{ml})$. The proteolytic reaction was stopped with DMEM (BioWhittaker) plus 10\% FBS (HyClone, Logan, UT). After an initial centrifugation $(8-10 \mathrm{~min}$ at $1000 \mathrm{rpm})$ the cells were resuspended, vortexed at maximum speed, and centrifuged a total of three times at the same rate. After a final trituration to break up all aggregates, the cells were filtered through a $74 \mu \mathrm{m}$ nitex mesh (Tetko, Inc., Elmsford, NY). The mixed glial cells so obtained were then resuspended and plated in previously prepared flasks. Flasks $\left(75 \mathrm{~cm}^{2}\right.$; Corning, Corning, NY) were coated with poly-Dlysine (200 $\mu \mathrm{g} /$ flask; Sigma, St. Louis, MO) for at least $1 \mathrm{hr}$, washed well, and allowed to air dry. Growth medium was DMEM plus 10\% FBS supplemented with $1.8 \mathrm{~g} / 1$ glucose, $2 \mathrm{~mm}$ glutamine, $10 \mathrm{~mm}$ HEPES, MEM essential vitamin mixture, nonessential amino acids (100 $\mu \mathrm{M}$ each), $1 \mathrm{~mm}$ sodium pyruvate, and PSF (100 U/ml penicillin, $100 \mu \mathrm{g} / \mathrm{ml}$ streptomycin, and $0.25 \mu \mathrm{g} / \mathrm{ml}$ Fungizone). After $24 \mathrm{hr}$, the flasks were placed on a rotary shaker for up to $5 \mathrm{hr}$ to release unattached cells and microglia, which were decanted, and fresh media were added. This procedure was repeated every $3 \mathrm{~d}$ until cells reached confluence (5-10 d). When confluent, flasks were trypsinized, and cells were expanded to uncoated flasks for further growth or to $35 \mathrm{~mm}$ tissue culture dishes (Falcon) for patch-clamp or staining procedures. For experiments at early time points, cells were plated directly onto $35 \mathrm{~mm}$ tissue culture dishes. The dishes contained glass coverslips and had been coated with $2 \%$ gelatin (Kodak, Rochester, NY) in Medium 199 (Life Technologies, Gaithersburg, MD) and 2\% FBS.

Immunocytochemical staining of cells. Before immunocytochemical staining the cells were fixed in $4 \%$ paraformaldehyde for $\geq 1 \mathrm{hr}$. After several washes the cells were placed in a blocking buffer containing 3\% goat serum, $1.5-3 \%$ BSA, and $0.1 \%$ Triton X-100 in $0.1 \mathrm{M}$ TBS, $\mathrm{pH} 7.4$, for $1 \mathrm{hr}$ to prevent nonspecific binding. Primary GFAP antibodies were diluted in the same buffer and allowed to react from $1 \mathrm{hr}$ to overnight. After several washes the cells were placed in a fluorescent and anti-rabbit IgG (Sigma) secondary antibody for $1-3 \mathrm{hr}$ in the dark. After several washes the dishes could be stored in $0.1 \mathrm{~m}$ TBS in the dark.

Hippocampal slice preparation. Hippocampal slices were prepared from 18- to 25-d-old male Wistar rats (Janigro et al., 1997a). Briefly, halothaneanesthetized rats were decapitated, and the heads were kept in ice-cold, oxygenated-modified artificial CSF composed of (in mM): $120 \mathrm{NaCl}, 3.1$ $\mathrm{KCl}, 4 \mathrm{MgCl}_{2}, 1 \mathrm{CaCl}_{2}, 1.25 \mathrm{KH}_{2} \mathrm{PO}_{4}, 26 \mathrm{NaHCO}_{3}$, and 10 dextrose. The whole brain was rapidly dissected out and glued on the stage of a vibratome, and $400-\mu \mathrm{m}$-thick slices were cut perpendicular to the longitudinal axis of the hippocampus. Slices were then stored at room temperature (usually $\sim 24^{\circ} \mathrm{C}$ ) in a recovery chamber containing the following oxygenated saline solution (in mM): $120 \mathrm{NaCl}, 3.1 \mathrm{KCl}, 1 \mathrm{MgCl}_{2}, 2 \mathrm{CaCl}_{2}, 1.25 \mathrm{KH}_{2} \mathrm{PO}_{4}, 26$
$\mathrm{NaHCO}_{3}$, and 10 dextrose. Both solutions were equilibrated with $95 \% \mathrm{O}_{2}$ plus $5 \% \mathrm{CO}_{2}$ to a final $\mathrm{pH}$ of 7.4 .

Perforated and whole-cell patch-clamp recordings from hippocampal slice or cultured glial cells. The experiments performed to elucidate the electrical behavior of in situ glial cells were performed with either a wholecell patch or perforated patch technique (Janigro et al., 1997a) from visually identified cells in the stratum radiatum of the hippocampal CA1 and CA3 regions. Astrocytes were initially identified morphologically based on the characteristic size and shape of their soma; this identification was further confirmed by histochemical analysis on biocytin-filled cells (R. D'Ambrosio, G. M. McKhann II, and D. Janigro, unpublished results). After at least $1 \mathrm{hr}$ spent in the holding chamber, slices were gently transferred to a submersion recording chamber where they were continuously perfused at a rate of $2-3 \mathrm{ml} / \mathrm{min}$ with freshly oxygenated solution. Recordings were performed at room temperature (range, 22$25^{\circ} \mathrm{C}$ ) in either the whole-cell or perforated patch configuration using an Axopatch 200A or an Axopatch 1C (Axon Instruments); temperature fluctuations allowed within the same experiment were $<1^{\circ} \mathrm{C}$. Seal formation was established under visual control, maintaining positive pressure in the patch electrode when entering into the slice. Slices were continuously perfused with a solution containing (in $\mathrm{mM}$ ): $120 \mathrm{NaCl}, 3$ $\mathrm{KCl}, 1.0 \mathrm{MgSO}_{4}, 1.25 \mathrm{KH}_{2} \mathrm{PO}_{4}, 26 \mathrm{NaHCO}_{3}, 2 \mathrm{CaCl}_{2}$, and 10 dextrose, equilibrated with $95 \% \mathrm{O}_{2}$ plus $5 \% \mathrm{CO}_{2}, \mathrm{pH}$ 7.4. Whole-cell patch pipettes were filled with (in $\mathrm{mM}$ ): 140 potassium gluconate, $1 \mathrm{MgCl}_{2}, 2$ $\mathrm{Na}_{2} \mathrm{ATP}, 0.3 \mathrm{NaGTP}, 10 \mathrm{HEPES}$, and 0.5 EGTA, final $\mathrm{pH} \mathrm{7.2.} \mathrm{For}$ perforated patch recordings, the antibiotic gramicidin was used at a concentration of $15 \mu \mathrm{g} / \mathrm{ml}$ in a solution containing (in mM): 35 HEPES, $70 \mathrm{KCl}, 70 \mathrm{KF}, 10 \mathrm{NaCl}$, and 1 EGTA, pH 7.30, with KOH. We routinely used KF to monitor patch-rupturing events. Accidental rupture of the seal was characterized by a large and sudden depolarization attributable to the blocking action of intracellular KF on potassium currents (Janigro et al., 1997a). Pipettes had a resistance of $\sim 5 \mathrm{M} \Omega$. Cell and pipette capacitance compensation, signal filtering (at $2 \mathrm{kHz}$ ), and series resistance compensation were routinely performed. Astrocytes were distinguished from neurons because of their electrical properties. Under current-clamp conditions, the differences between neuronal and glial cells is most evident; both pyramidal and interneuronal cells fire regular trains or bursts of action potentials after depolarizing current injections or at rest and are characterized by RMP close to $-65 \mathrm{mV}$. In contrast, spontaneous or depolarization-induced action potentials were never observed in astrocytes. Similarly, spontaneous and evoked postsynaptic potentials, a hallmark of neuronal cells, were never encountered during glial recordings.

The intracellular solution used for whole-cell recordings from cultured neocortical astrocytes contained (in $\mathrm{mM}$ ): 120 potassium aspartate, 2 $\mathrm{MgCl}_{2}, 1 \mathrm{CaCl}_{2}, 5$ EGTA-KOH, 10 HEPES, $2 \mathrm{Na}_{2} \mathrm{ATP}$, and 0.5 $\mathrm{Na}_{2}$ GTP, pH 7.30, with KOH. The estimated free calcium concentration was $\sim 10^{-8}$ M. Perforated recordings were obtained with the same solution used for slice experiments (see above). Cells were continuously bathed with a solution containing (in $\mathrm{mM}$ ): $125 \mathrm{NaCl}, 3 \mathrm{KCl}, 2 \mathrm{MgCl}_{2}, 1$ $\mathrm{CaCl}_{2}, 10 \mathrm{HEPES}$ (whole-cell) or $35 \mathrm{HEPES}$ (peforated patch), and 10 dextrose, $\mathrm{pH} 7.3$, with $\mathrm{NaOH}$, at a flow rate of $2 \mathrm{ml} / \mathrm{min}$. Solutions were exchanged through small diameter rigid plastic tubing positioned close $(100 \mu \mathrm{m})$ to the cell. Detectable effects after switching to a drugcontaining solution are usually evident within $15 \mathrm{sec}$.

Pair patch-clamp recordings were performed from neighboring astrocytes in culture. Combinations of perforated/perforated and whole cell/ whole cell were used. Two patch-clamp amplifiers (Axopatch 200A and Axopatch 1C) were grounded to a common ground point and were used for both voltage- and current-clamp recordings. Coupling ratios were obtained during simultaneous pair recordings from morphologically (and most often electrically) coupled cells and were determined as the ratio between $V_{2}$ and $V_{1}$, where $V_{1}$ and $V_{2}$ represent the current deflections measured in response to current injection in cell 1.

All resting membrane potentials are reported after correction of tip potentials; tip potential (usually $<3 \mathrm{mV}$ ) was measured after withdrawal of the pipette. Input resistance was determined by measuring in voltage clamp the steady-state current evoked by brief $(10 \mathrm{msec})$ hyperpolarizing pulses (from a holding potential of $-60 \mathrm{mV}$ ); alternatively, brief hyperpolarizing currents were injected during current-clamp experiments. Cell capacitance was analogically determined by Axopatch 1C. Statistical analysis was performed by ANOVA. Function fitting and data interpolation were performed by Origin (version 4.1, Microcal). 
A

Figure 1. Bimodal distribution of resting potentials in cultured neocortical astrocytes. $A, B$, Whole-cell and gramicidinperforated data, respectively. Data were fitted by a double Gaussian function that gave peaks at -67 and -44 and -66 and $-43 \mathrm{mV}$ for whole-cell and perforated recordings, respectively. The mean resting potential values were $59.6 \pm 1.6$ and $60.1 \pm$ $1.6 \mathrm{mV}$ for whole-cell and perforated recordings, respectively. Note that regardless of the patch-clamp variation used, a wide range of potentials could be recorded, and the peak values of resting potentials similarly did not depend on the technique used. Thus, intracellular dialysis or damage during transition from cell attached to whole cell could not be held responsible for the depolarized membrane potentials measured in a large percentage of the cells. $C 1$, $C 2$, Whole-cell and perforated recordings from different cells (holding potential, -40 ; test potentials, from -80 at $20 \mathrm{mV}$ intervals; the initial step was applied to $-90 \mathrm{mV}$ for $5 \mathrm{msec}$ ). Note the variable profiles of ionic currents recorded. The dashed line indicates $0 \mathrm{nA}$

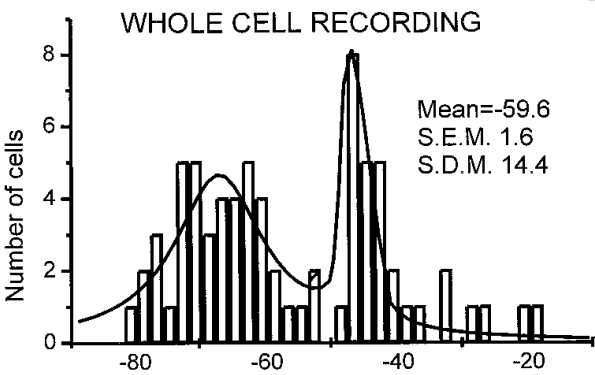

C1

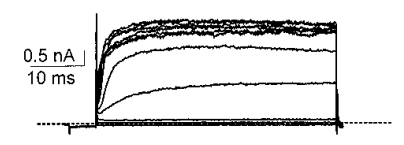

B

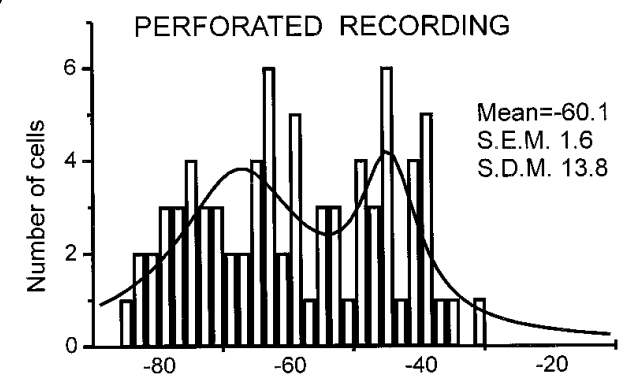

$\mathrm{C} 2$
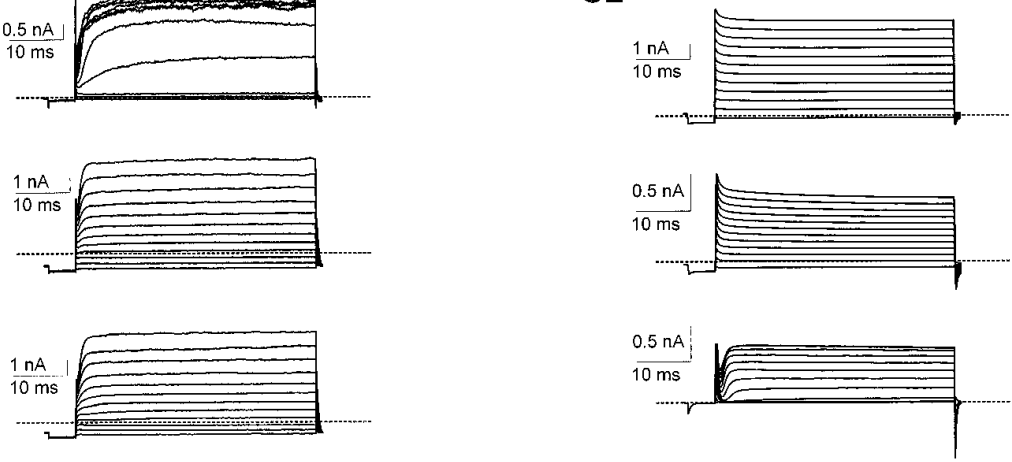

\section{RESULTS}

\section{Whole-cell and perforated patch-clamp recordings from cultured cortical astrocytes}

Whole-cell current-clamp recordings from cortical astrocyte cultures revealed a range of RMPs from -22 to $-82 \mathrm{mV}(n=78$ cells). The distribution of RMPs among these cells was roughly bimodal (Fig. 1A). The same cells under voltage clamp were characterized by a variety of electrical profiles, including cells displaying inward-going rectification, outward rectification, multiple anomalous rectification regions, or nearly ohmic behavior (e.g., Fig. 1C1,C2; also see Figs. 5, 9). Because several possible explanations, including cell injury, could have accounted for this wide range of resting membrane potentials, we performed a number of experiments to investigate the mechanisms responsible for this electrical heterogeneity.

To ensure that cells with RMP positive to $-80 \mathrm{mV}$ were not more depolarized because of injury during whole cell penetration or because of intracellular dialysis of cytoplasmic components necessary for RMP maintenance, recordings were performed using the perforated patch technique with the anion-impermeant antibiotic gramicidin (Rhee et al., 1994; Janigro et al., 1997a). The gramicidin pipette solution included $70 \mathrm{~mm} \mathrm{KF}$ in replacement of $70 \mathrm{~mm} \mathrm{KCl}$. When transition from the perforated to the whole-cell configuration accidentally occurred, a rapid depolarization to $\sim 0$ $\mathrm{mV}$ was seen as fluoride entered the intracellular compartment; data obtained under these conditions were not used. Stable perforated patch-clamp recordings were obtained from 73 cultured cortical astrocytes. The range, distribution, and mean values of RMP in these virtually intact cells were very similar to those found in whole-cell recordings (Fig. $1 B)(p=0.84)$.

Cultured cortical astrocytes develop into two distinct morphological phenotypes: flat and stellate or processed (Raff et al., 1983; Ransom and Sontheimer, 1995; Guatteo et al., 1996). Thus, an alternative factor accounting for the heterogeneity described above may have been attributable to sampling from two grossly heterogeneous subpopulations of cells. Both cell types were examined using either the perforated or the whole-cell patch-clamp recording configuration (Fig. 2). Figure 2, $A$ and $B$, shows representative fields used for our experiments containing several $\mathrm{GFAP}^{+}$cells. Flat astrocytes are indicated by white arrows, whereas process-bearing astrocytes are indicated by open arrows. Both cell types thus coexisted in culture and formed intercellular contacts. There was no difference in the range $(-82$ to -22 and -85 to $-32 \mathrm{mV}$ for process-bearing and flat cells, respectively), distribution, or mean values of RMP $(-58 \pm 1.6$ and $-59 \pm 1.7$ $\mathrm{mV}$, mean $\pm \mathrm{SEM}$; SD of the means were \pm 13.7 and \pm 14.4 , respectively) recorded from flat cells versus stellate cells ( $n=79$ and 72 , respectively; $p=0.69$ ).

Because damaged cell membranes can be detected by measurements of exceedingly low cell input resistance, and because "leaky" membranes are likely to cause low resting membrane potential values, we assessed a possible correlation between RMP and cell input resistance for both whole-cell and perforated patch recordings. If a subpopulation of cells was more depolarized because of cellular injury or a leaky seal, we expected to find a lower cellular resistance in more depolarized cells (Fig. 3). However, there was no statistically significant correlation between cell resting membrane potential and input resistance in either the whole-cell or perforated patch recordings (slope, $-0.26 \mathrm{M} \Omega / \mathrm{mV}$; $r=0.08$; and $-0.39 \mathrm{M} \Omega / \mathrm{mV} ; r=0.05$, respectively). Perforated patch-clamp recordings had a significantly higher membrane resistance than the whole-cell recordings ( $34 \pm 6$ and $124 \pm 16 \mathrm{M} \Omega$ for whole-cell and perforated recording, respectively $(p<0.01)$ (see Rhee et al., 1994).

\section{Whole-cell and perforated patch-clamp recordings from hippocampal slice astrocytes}

Cell culturing affects the time-dependent phenotypic expression of ion channels in glial cells. Thus, a possible confounding effect of tissue culture artifacts had to be taken into account. To confirm 
A
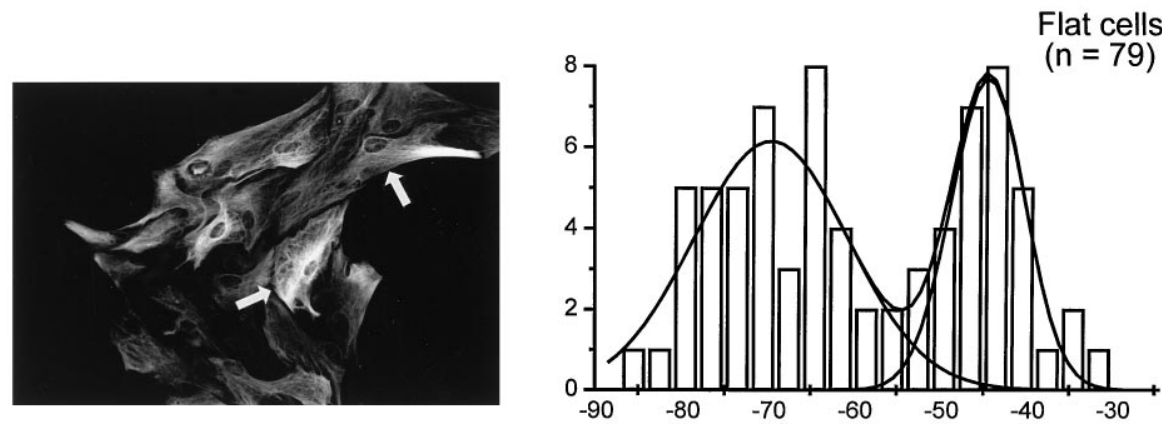

B
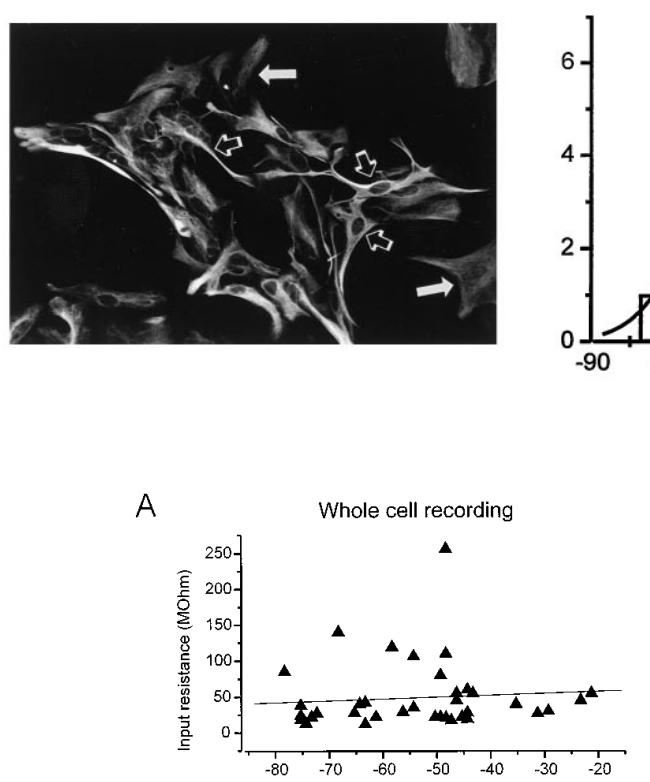

B

A
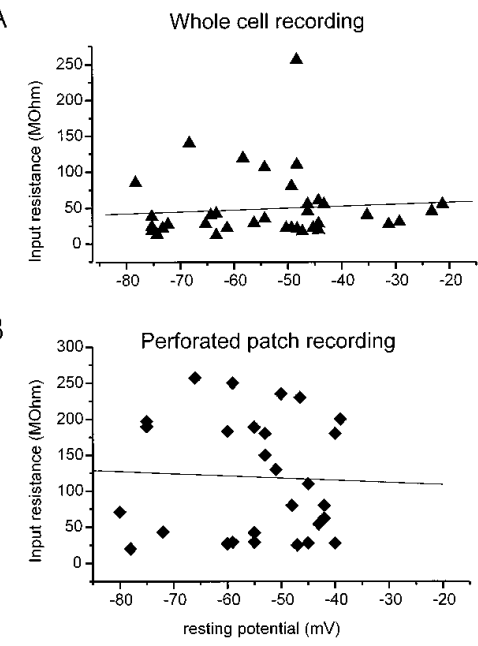

Figure 3. Depolarized resting potentials are not attributable to damage to the cultured astrocyte membrane during seal formation or after establishment of the whole-cell configuration. $A$, Whole-cell recordings revealed a range of RMPs that correlated poorly with cell membrane input resistance. Because several of the recordings were performed from single cells coupled to a large number of neighboring astrocytes, low input resistance values were expected. $B$, As for cells recorded from by the whole-cell configuration, gramicidin-perforated astrocytes displayed no correlation between RMP and $R_{\mathrm{IN}}$. Note that these recordings were characterized by a much higher input resistance because of the higher access resistance through the membrane patch.

that the RMP heterogeneity that we found in cultured glia was not simply attributable to culturing conditions, a combination of whole-cell and perforated patch-clamp recordings was performed from 27 CA1 stratum radiatum hippocampal slice astrocytes obtained from rats at $18-25 \mathrm{~d}$ postnatally. At this not fully mature time point, most but not all of the developmental changes in glial cell physiology are completed (Bordey and Sontheimer, 1997). As
Figure 2. Lack of correlation between morphological appearance of cultured astrocytes and cell resting potential. The photographs represents the typical cell density and morphology characteristic of the preparation used for this study. Cells were stained and processed for GFAP immunocytochemistry; these cultures were $99 \% \mathrm{GFAP}^{+}$. Cells could be easily differentiated as flat (or polygonal, "pancake") (white arrows) or stellate astrocytes (open arrows) by visual inspection under phase contrast. Some cultures predominantly contained cells of one morphological subtype $(A)$, whereas most cultures contained a mixture of the two cell morphologies $(B)$. Note that both flat $(A)$ and stellate cells $(B)$ displayed a marked variability of RMP values. These could be fitted by a bimodal distribution with two peaks at -65 and $-43 \mathrm{mV}$ (processbearing cells) and -69 and $-45 \mathrm{mV}$ (flat astrocytes). 


\section{Hippocampal slice astrocytes}

Figure 4. The heterogeneous distribution of astrocyte resting potentials is not an artifact attributable to cell culture. In situ hippocampal astrocytes recorded in the stratum radiatum of the CA1 subfield are, similar to cultured neocortical astrocytes, characterized by variability of RMP with a roughly bimodal distribution. The right panel shows the lack of statistically significant correlation between cell resting potential and input resistance in these cells $(r=0.2)$.
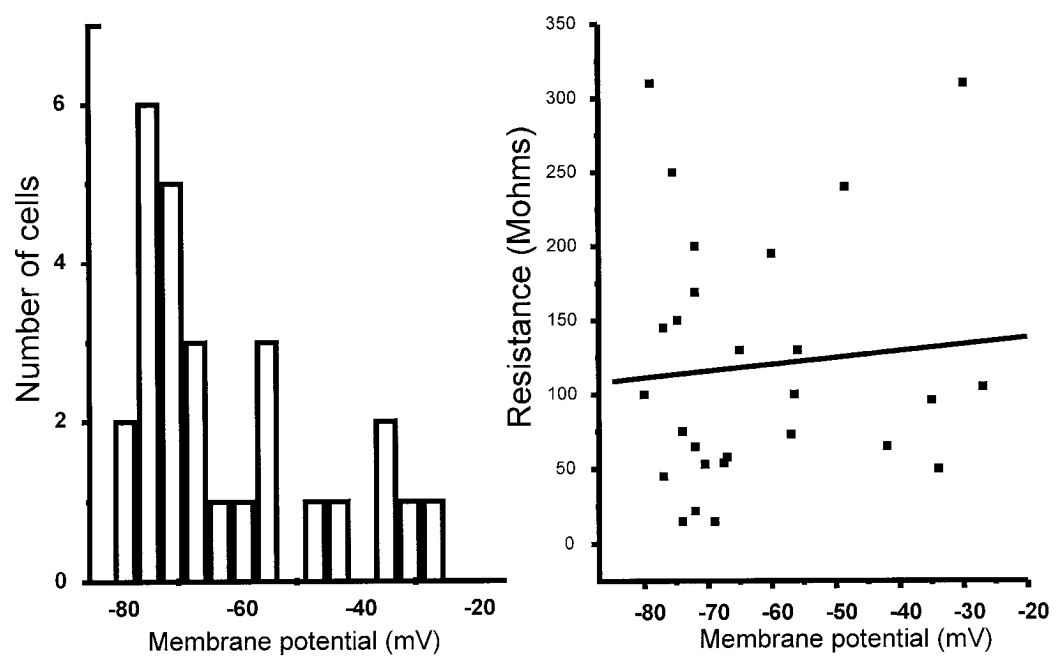

\section{Effect of time in culture on RMP variability}

The expression of potassium and sodium channels by astrocytes is believed to be developmentally regulated. In cultures of hippocampal and cortical astrocytes and in hippocampal slice astrocytes, expression of inwardly rectifying $\mathrm{K}^{+}$channels increases, whereas outward $\mathrm{K}^{+}$currents and voltage gated inward $\mathrm{Na}^{+}$ currents decrease over time (Barres et al., 1990; Sontheimer et al., 1992). These changes are thought to result in a gradual negative shift of resting membrane potential over time. We thus investigated whether the measured RMP values correlated with time in culture.

Cultured astrocytes were recorded from at varying times in culture ranging from 2 to $32 \mathrm{~d}$. There was no significant relationship between time in culture and RMP regardless of the electrophysiological configuration used to measure cell RMP (Fig. 5B). In particular, we did not find a higher percentage of more depolarized cells after shorter times spent in culture. Depolarizationevoked $\mathrm{Na}^{+}$currents were observed only in a minority $(17 \%)$ of the cultured cells. $\mathrm{Na}^{+}$currents were detected after both shorter and longer times in culture (Fig. 5A1,A2); the presence of $\mathrm{Na}^{+}$ currents did not correlate with RMP.

\section{Effect of $\mathrm{Na}^{+} / 2 \mathrm{HCO}_{3}$ - co-transporter on RMP variability}

Astrocytes are endowed with an electrogenic $\mathrm{Na}^{+} / 2 \mathrm{HCO}_{3}^{-}$cotransporter that has an estimated reversal potential of $-95 \mathrm{mV}$ and helps to maintain $\mathrm{pH}$ homeostasis in response to neuronal activity (Rose and Ransom, 1996). Because of its electrogenic nature $\left(1 \mathrm{Na}^{+}\right.$for $2 \mathrm{HCO}_{3}^{-}$taken up by the cell), this co-transport mechanism may be involved in the regulation of glial RMP. O'Connor et al. (1994) have shown that some of the variability of cultured astrocyte resting membrane potential detected in HEPES-buffered recording solution is lost in $\mathrm{CO}_{2} / \mathrm{HCO}_{3}^{-}$buffered solution because of the voltage-dependent hyperpolarizing effect of the $\mathrm{Na}^{+} / 2 \mathrm{HCO}_{3}^{-}$co-transporter.

To determine how much of the RMP heterogeneity found in our experiments was attributable to a lack of $\mathrm{Na}^{+} / 2 \mathrm{HCO}_{3}^{-}$transporter activity in HEPES-buffered solution, we performed experiments similar to those by O'Connor et al.; we thus initially used the whole-cell patch-clamp recording configuration (Fig. 6). Experiments were then repeated using the more physiological gramicidin-perforated patch-clamp configuration to determine whether the $\mathrm{Na}^{+} / 2 \mathrm{HCO}_{3}^{-}$co-transporter effect on RMP would be present under conditions of unaltered intracellular anion concentration.

In agreement with O'Connor et al. (1994), whole-cell recordings revealed that by switching from a HEPES-buffered solution to HEPES plus $\mathrm{CO}_{2} / \mathrm{HCO}_{3}^{-}$media, a hyperpolarization of cultured astrocytes occurred; this response is consistent with the activation of the inward electrogenic $\mathrm{Na}^{+} / 2 \mathrm{HCO}_{3}^{-}$transporter current. More depolarized cells had a larger hyperpolarizing response to $\mathrm{CO}_{2} / \mathrm{HCO}_{3}^{-}$(Fig. $6 \mathrm{~B}$ ). Because no bicarbonate was added to the intracellular pipette solution, the extrapolated reversal potential for the transporter was more negative than the previously reported value of $-95 \mathrm{mV}$ (O'Connor et al., 1994). The hyperpolarizing response to $\mathrm{HCO}_{3}^{-}$was rapidly reversed on returning to HEPES-buffered solution (no $\mathrm{HCO}_{3}^{-}$).

Changing from HEPES-buffered solution to HEPES plus $\mathrm{CO}_{2} / \mathrm{HCO}_{3}^{-}$-buffered solution during perforated patch-clamp recording caused a different cellular response. With exposure to $\mathrm{HCO}_{3}^{-}$, an initial hyperpolarization that was larger in more depolarized cells was observed. However, this initial response was immediately followed by a spontaneous return to baseline RMP in nearly all cells examined (Fig. 6A). After washout with HEPES-buffered solution (no $\mathrm{HCO}_{3}^{-}$), cells transiently depolarized before returning to their original RMP. These results demonstrate that under recording conditions that allow preservation of physiological anionic gradients, heterogeneity of RMP is not the result of $\mathrm{Na}^{+} / 2 \mathrm{HCO}_{3}^{-}$co-transport. Consistent with this finding, hippocampal slice astrocyte recordings confirmed RMP heterogeneity in the presence of $\mathrm{CO}_{2} / \mathrm{HCO}_{3}^{-}$-buffered extracellular solution (see above and Discussion).

\section{Possible role of $\mathrm{K}_{\text {(ATP) }}$ and $\mathrm{I}_{\mathrm{Na}}$}

Neuronal, cardiac, and nonexcitable cells have been shown to express an ATP-sensitive conductance involved in the regulation of RMP and excitability (Janigro et al., 1993; Erdemli and Krnjevic, 1994). We exposed cultured astrocytes $(n=9)$ to $5-15 \mu \mathrm{M}$ nicorandil (Janigro et al., 1997b) to induce opening of $\mathrm{K}_{\text {(АTP) }}$ channels, if present. The resting membrane potential (range, -60 to $-84 \mathrm{mV}$ ) and input resistance of these cells were virtually unaffected after application of this $\mathrm{K}_{\text {(АTP) }}$ channel agonist. We 
A1

7 days in vitro

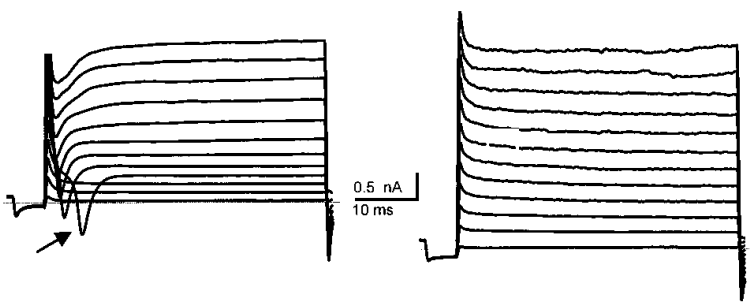

A2

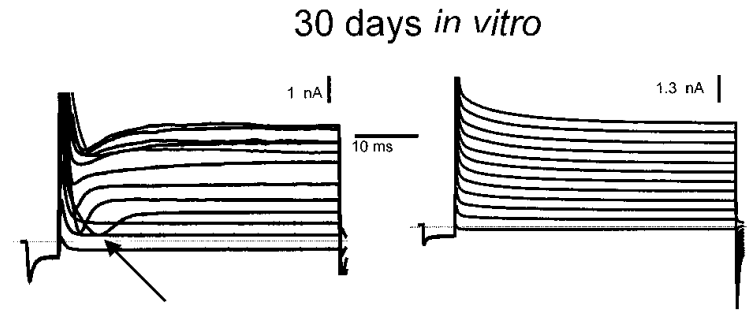

B

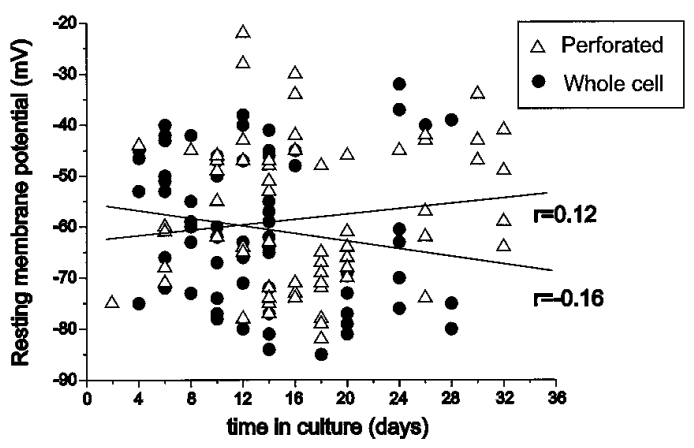

Figure 5. The variability in RMP values does not correlate with different time spent under culturing conditions or with the expression of $\mathrm{Na}^{+}$ currents. $A 1, A 2$, Whole-cell recordings from cultured astrocytes exposed to depolarizing voltage-clamp protocols. Cells kept in culture for $7 \mathrm{~d}(A 1)$ and $30 \mathrm{~d}(A 2)$ both expressed inward currents carried by sodium in a minority of cells (arrows, left panels). Depolarization evoked only outward currents in most cells at both time points (right panels). Identical voltageclamp protocols were used in $A 1$ and $A 2$. Holding potential, $-60 \mathrm{mV}$; depolarizing steps of $100 \mathrm{msec}$ duration were preceded by a short step to -100 (to activate $\mathrm{I}_{\mathrm{Na}}$ fully) and were applied at $+10 \mathrm{mV}$ increments. $B$, Perforated (open triangles) or whole-cell recording (filled circles) RMPs did not correlate with the time spent in culture.

subsequently performed experiments with no ATP in our intracellular pipette solution to allow for activation of channels, if present. Whole-cell patch-clamped cultured cells $(n=6)$ were then exposed to 5-50 $\mu \mathrm{M}$ glibenclamide, a $\mathrm{K}_{(\text {ATP }}$ channel blocker (Janigro et al., 1993). The RMP (range, -49 to $-76 \mathrm{mV}$ ) and input resistance of these cells were not altered during $\mathrm{K}_{\text {(АTP) }}$ antagonist treatment, consistent with a lack of $\mathrm{K}_{(\text {(АTP) }}$ channel expression by cultured neocortical astrocytes. We thus did not find evidence for a contribution of $\mathrm{K}_{\text {(ATP) }}$ channels to RMP in cultured astrocytes.

\section{Effects of intercellular gap junction coupling on astrocyte heterogeneity}

To address how changes in gap junctional coupling alter electrophysiological recordings from astrocytes, we performed prolonged whole-cell and perforated patch-clamp recordings from cultured astrocytes and in situ CA1 and CA3 glia. When recording from these cells, several dynamic changes were observed during prolonged, perforated recordings; these cells appeared to undergo sudden (and reversible) changes in current-voltage profiles that were clearly not attributable to changes in series resistance (Fig. 7) or to acquire (or lose) pharmacological sensitivity to known blockers of potassium currents (Fig. 8). During prolonged pair recordings from neighboring cells, we were able to monitor closely these dynamic changes (Fig. 9).

\section{Dynamic changes during prolonged voltage-clamp recordings}

During prolonged recordings from either cultured neocortical or radiatum astrocytes, sudden (and often reversible) changes in the electrophysiological properties were observed. Figure $7 A$ shows the results from a cultured cell where the changes in quasi steady-state $I-V$ relationship were monitored over time (wholecell recording). The cell was voltage-clamped at $-60 \mathrm{mV}$, and ramp voltage commands (from -160 to $100 \mathrm{mV}$ ) were imposed. This procedure caused the activation of a whole-cell current characterized by a region of inward-going rectification at membrane potentials positive to rest $(-52 \mathrm{mV}$ in this cell). Five minutes after establishing the whole-cell configuration, a sudden increase of the ramp-evoked current was observed $(t=5 \mathrm{~min})$. The net current responsible for this electrophysiological change was also characterized by a region of decreased slope conductance; however, the additional current was nearly abolished at depolarized potentials, as demonstrated by the plot of the difference current obtained by subtracting the current at $t=5 \mathrm{~min}$ from the initial current. These whole-cell current changes were reversible with an additional $12 \mathrm{~min}$ of recording $(t=17 \mathrm{~min}$ in Fig. $7 A)$. This anomalous behavior was seen in the majority of the recordings (18 of 23 cells) and was characterized by either sudden current increase or loss; the acquired (or dissipated) currents were characterized by either inward- or outward-going rectification or had linear near-ohmic current-voltage profiles. It was unlikely that these current profile changes were attributable to changes in series resistance because of their rapid reversibility (also see Fig. $7 B$ ).

Figure $7 B$ shows a similar putative spontaneous change in coupling in a hippocampal slice CA3 stratum radiatum cell. To establish that these changes were not attributable to changes in series resistance $\left(R_{\mathrm{S}}\right)$, we measured cell capacitance (at $-70 \mathrm{mV}$ ) under both "coupled" and "uncoupled" conditions. The current change during the uncoupling event was compared with the change resulting from $R_{\mathrm{S}}$ compensation in the same cell (Fig. $7 B$, inset). The reversible coupled to uncoupled transition was characterized by a decrease in capacitance (from 8 to $2.5 \mathrm{pF}$ ) with loss of nearly $50 \%$ of the recorded resistive current, without any alteration in $R_{\mathrm{S}}$ (compensated at $80 \%$ ). In contrast, $80 \% R_{\mathrm{S}}$ compensation of the coupled configuration resulted in a much smaller current change that was independent of any change in cell capacitance.

Similar dynamic changes, possibly attributable to alterations in coupling between cells, were also observed during prolonged recordings obtained by using the gramicidin-perforated patchclamp technique. Thus, dynamic changes did not depend on washout (or rundown) of intracellular components essential for maintenance of gap junction conductance.

\section{Sensitivity to extracellular $\mathrm{Cs}^{+}$}

We interpreted the above results by assuming that, during prolonged recordings, sudden current changes were reflections of increased (or decreased) coupling. A prediction of this hypothesis is that prolonged recordings may similarly affect the pharmaco- 
A

\section{Perforated patch}
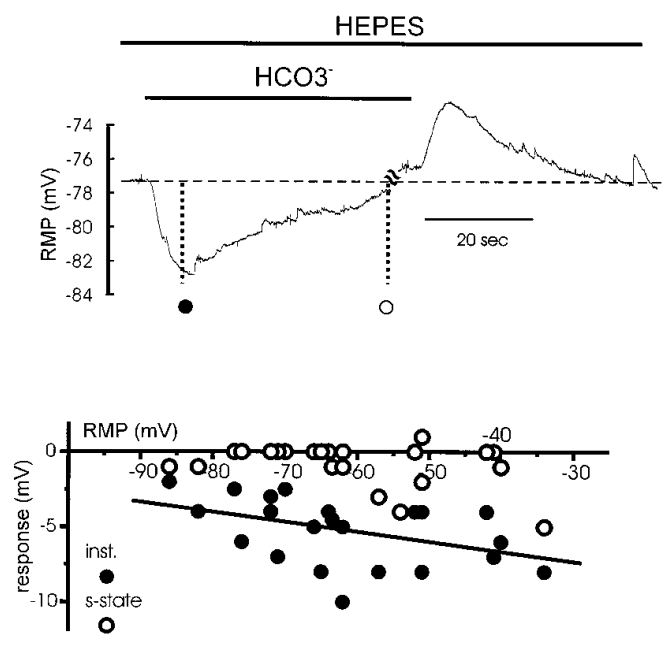

B

\section{Whole Cell}
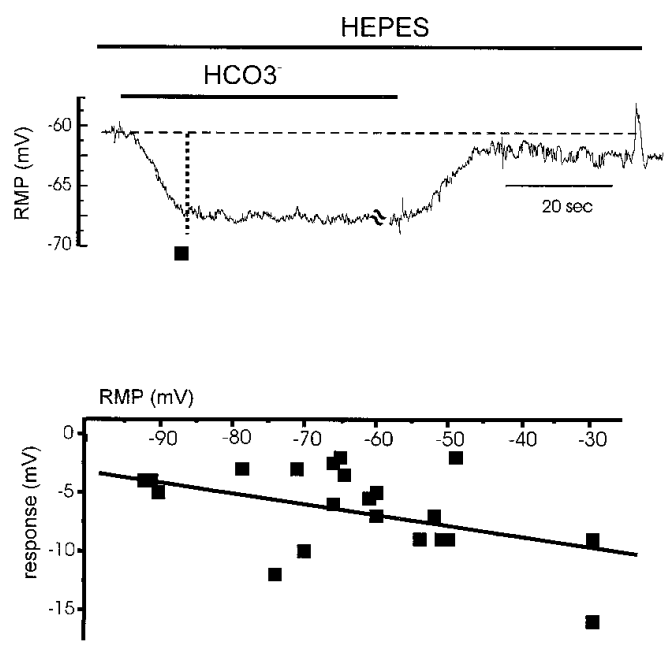

Figure 6. $\mathrm{Na}^{+} / 2 \mathrm{HCO}_{3}^{-}$co-transporter activity affects cell resting membrane potential during whole-cell recordings but not in cells with intact anion gradients. $A$, Perforated patch-clamp recording from a cultured neocortical astrocyte under current-clamp conditions $\left(I_{\text {pipette }}=0\right.$ nA). Note that application of $\mathrm{HCO}_{3}^{-}$caused a transient hyperpolarization followed by a prompt return to a pre- $\mathrm{HCO}_{3}^{-}$value. The peak of the hyperpolarizing response is marked by a filled circle, whereas the steady-state response is indicated by an open circle. The bottom graphs illustrate the cumulative results from these experiments. Note that in nearly all of the 22 cells recorded from in the perforated patch-clamp configuration, hyperpolarizations seen at the peak of the responses were not present at steady state ( filled symbols, peak; open symbols, steady state). In contrast, during whole-cell recordings no difference between steady-state and peak response was seen $(B)$. The hyperpolarizing responses on exposure to $\mathrm{HCO}_{3}^{-}$for the 21 whole-cell recordings are shown.

logical sensitivity of these whole-cell currents. Because inward potassium currents in glia are exquisitely sensitive to extracellular cesium (Ransom and Sontheimer, 1995), we bath-applied 1-3 mM $\mathrm{Cs}^{+}$to cells depolarized with high extracellular potassium (25 $\mathrm{mM}) . \mathrm{Cs}^{+}$reduced $\mathrm{I}_{\mathrm{IR}}$ currents, as reported previously by us and others (Ransom and Sontheimer, 1995; Guatteo et al., 1996; Janigro et al., 1997a).

Increasing $\left[\mathrm{K}^{+}\right]_{\text {out }}$ readily depolarized cultured glia (Fig. 8). Because a component of this depolarization is believed to result from influx of potassium through $\mathrm{Cs}^{+}$-sensitive, inwardly rectifying channels, we attempted to block the $\left[\mathrm{K}^{+}\right]_{\text {out }}$-induced depolarization by pre-exposure to $2 \mathrm{~mm} \mathrm{Cs}^{+}$. Although cesium often completely blocked the high $\left[\mathrm{K}^{+}\right]_{\text {out }}$ depolarization (Fig. 8A1), many cells were $\mathrm{Cs}^{+}$-insensitive. However, during prolonged perforated patch-clamp recordings lasting 60-120 min, a $\mathrm{Cs}^{+}$. insensitive cell frequently behaved as $\mathrm{Cs}^{+}$-sensitive and vice versa.

Examples of these recordings are shown in Figure 8; a cell that initially responded to $\mathrm{Cs}^{+}$application (Fig. 8A1) over time displayed $\mathrm{Cs}^{+}$insensitivity, as demonstrated by the lack of effect of $\mathrm{Cs}^{+}$on $\mathrm{K}^{+}$-induced depolarization (Fig. 8A2). This phenomenon was observed four times in seven prolonged recordings and was found to occur in either direction; $\mathrm{a} \mathrm{Cs}^{+}$-sensitive cell could become $\mathrm{Cs}^{+}$-insensitive, or a $\mathrm{Cs}^{+}$-insensitive cell could become $\mathrm{Cs}^{+}$-sensitive (e.g., Fig. 8B1,B2). A possible interpretation of these results is that dynamic changes in intercellular coupling revealed (or concealed) ion channels sensitive to extracellular $\mathrm{Cs}^{+}$. Similar results were obtained by using $\mathrm{Ba}^{2+}$, a blocker of glial potassium channels that similarly prevents potassium conductance through inwardly rectifying channels (Ransom and Sontheimer, 1995).

\section{Recordings from coupled astrocyte cell pairs}

Because of the nonspecific effects of the uncoupling agents halothane, octanol, and anandamide on potassium channels (McKhann et al., 1997), we were unable to test pharmacologically whether segregated ion channel expression was an intrinsic property of morphologically coupled glia. We used an alternative (and more direct) approach and performed prolonged perforated patch-clamp recordings from visually identified isolated pairs of cells $(n=6)$ to determine whether dynamic changes in intercellular coupling over time would change the electrophysiological characteristics of recordings from astrocytes. Dynamic changes were observed in all six pairs of cells.

For these experiments, we used the perforated recording technique to allow for protracted recordings from intact (i.e., nondialyzed) cells (Fig. 9). To quantify the amount of intercellular coupling, two types of recordings were performed. First, both cells were current-clamped at their individual RMP, and current was injected into the first cell (Fig. 9, Cell 1); the resulting voltage change was recorded in the second cell (Fig. 9, Cell 2). Subsequently, whereas Cell 1 was voltage-clamped at $-60 \mathrm{mV}$ and then subjected to a voltage-clamp protocol, Cell 2 was currentclamped, and the voltage changes were measured. Both of these procedures were then reversed to assess whether the degree of coupling between the two cells was symmetric. In the pair depicted in Figure 9, cells were initially characterized by a low degree of coupling. Injection of current in Cell 1 caused a modest, almost negligible voltage deflection in Cell 2. Consequently, voltage-clamp protocols applied to Cell 1 were characterized by minor voltage changes in Cell 2 . These voltage steps evoked a large outwardly rectifying current in Cell 1, whereas identical protocols elicited a qualitatively dissimilar current in Cell 2. 
A
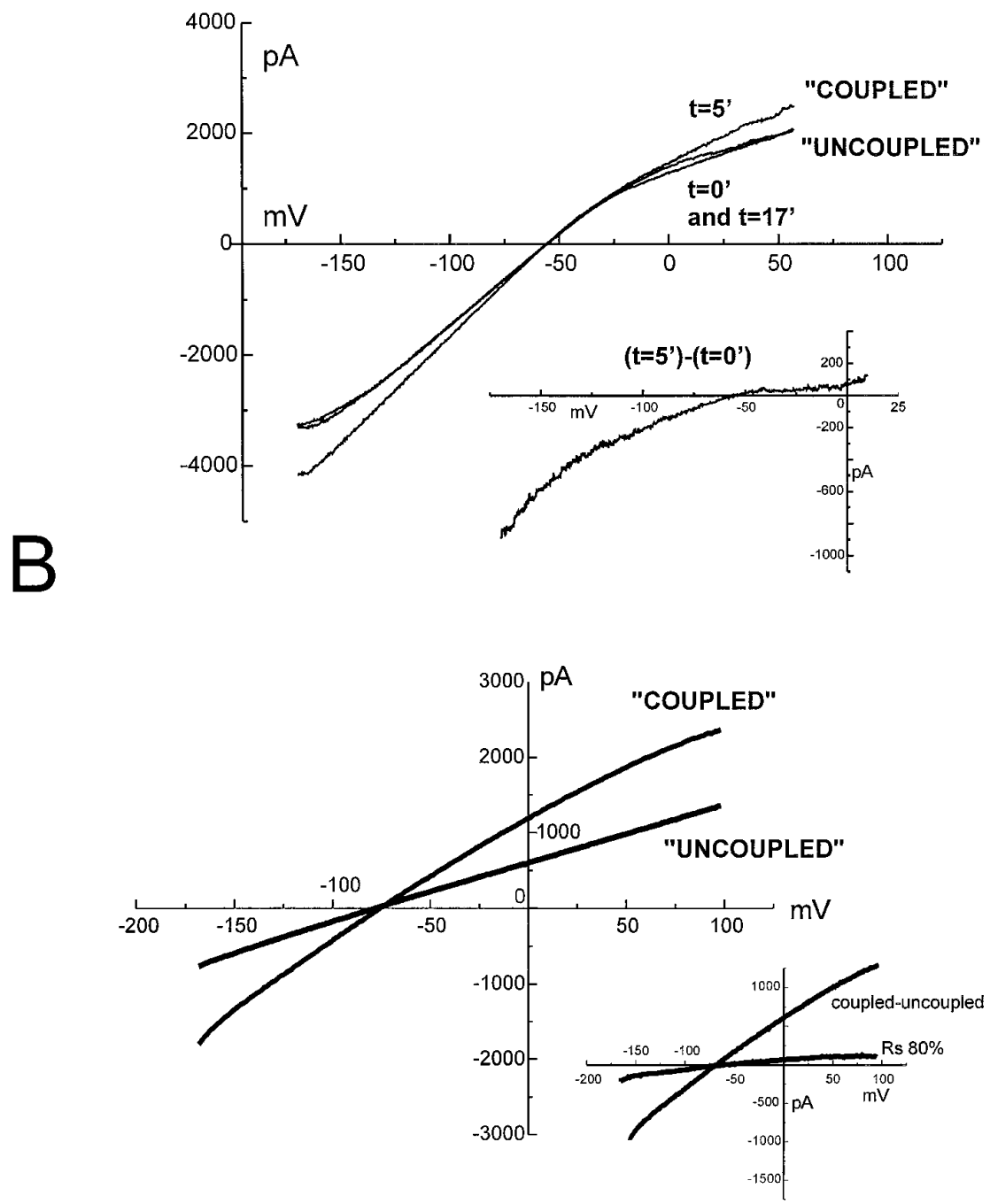

INTERPRETATION
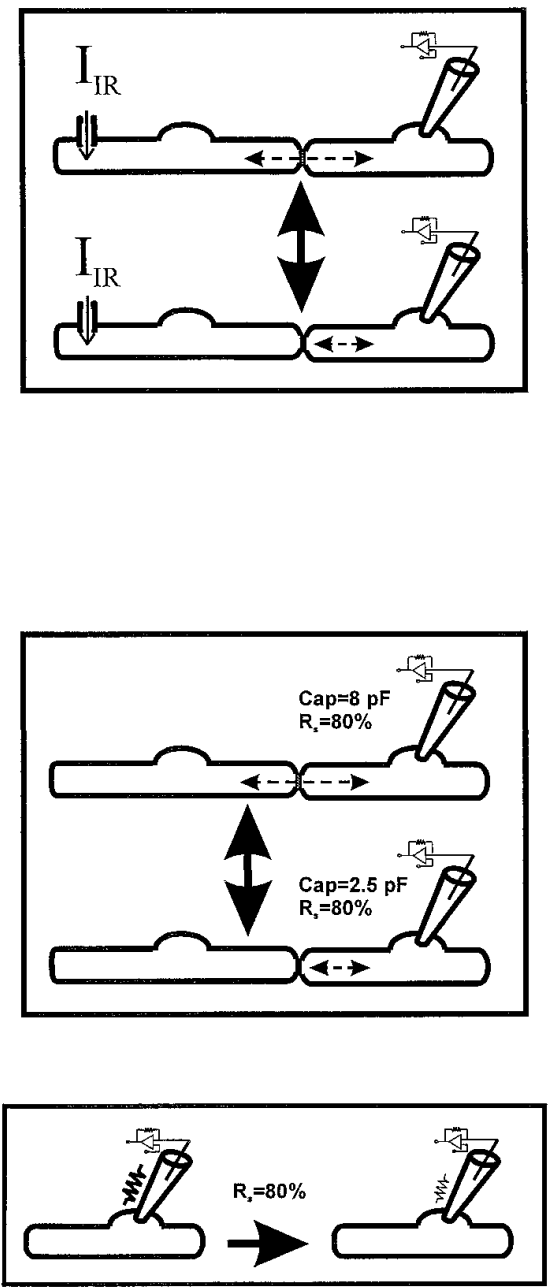

Figure 7. Dynamic and reversible changes in cell-to-cell coupling are not attributable to changes in series resistance. $A$, Changes in whole-cell currents observed during prolonged recording (cultured astrocyte). The cell was voltage-clamped at $-60 \mathrm{mV}$, and -160 to $100 \mathrm{mV}$ ramp commands were applied at $1 \mathrm{~min}$ intervals. Inset, Current obtained by subtracting the initial whole-cell current from the current obtained at 5 min. Note that this change in whole-cell current was fully reversible with time $(t=17 \mathrm{~min})$. A diagrammatic representation of these putative coupling and uncoupling events is also shown. $I_{I R}$ represents the inward-rectifying channels presumably located in the cell distal to the recording pipette. $B$, Whole-cell current changes associated with coupling and uncoupling can be distinguished from changes in series resistance $\left(R_{S}\right)$. A hippocampal CA3 astrocyte in situ was voltage-clamped as in $A$; note the sudden change in whole-cell current (uncoupled vs coupled). Inset, Current obtained by subtraction of the two current traces shown in the main panel. The current acquired after $80 \%$ compensation of $R_{\mathrm{S}}$ is also shown for comparison. The diagram (right panel) describes both experimental conditions (i.e., changes in junctional resistance vs changes in $R_{\mathrm{S}}$ ).

Figure 9, inset, shows the $I-V$ relationships of Cell 1 under conditions of low coupling (open circles). After several minutes, an additional current component was evident in Cell 2; the inset at the bottom right of the figure shows the $I-V$ relationship obtained in this cell under low coupling (open circles) and after the activation of this novel current component (squares). Note that under these conditions the $I-V$ profile of the currents evoked in Cells 1 and 2 were virtually identical, and that the voltage protocols elicited in one voltage-clamped cell were reflected by a large voltage transient in its current-clamped neighboring counterpart.

\section{DISCUSSION}

Because of the crucial role that resting potential plays in the control of neuronal firing, it is not surprising that neuronal
RMP has been extensively investigated. Minimal variations of neuronal RMP may affect output from effector cells, transduction of synaptic currents, and synaptic plasticity (Janigro and Schwartzkroin, 1988; Artola et al., 1990; Janigro et al., 1997a). Less is known on how glia regulate RMP. Our results, together with a review of the reported spectrum of glial RMP (Fig. 10), demonstrate that astrocyte RMPs are not homogenous. Of note, most studies with highly negative ranges or mean membrane potentials used exclusion criteria that defined the limit of depolarization of the cells that were included for analysis. In contrast, studies that did not use exclusion criteria reported a wide range of RMPs.

We found intrinsic heterogeneity of RMP among astrocytes from within cortical regions (neocortex and hippocampus). We 
Figure 8. Dynamic changes in the sensitivity to potassium channel blockers applied extracellularly. $A 1$, Recording from a cultured cell initially displaying $\mathrm{Cs}^{+}$sensitivity. Note that application of $\mathrm{KCl}(25 \mathrm{~mm}$; $\mathrm{NaCl}$ was decreased to preserve osmolarity) caused a depolarization of the cell that was entirely prevented by pre-exposure to $2 \mathrm{mM} \mathrm{Cs}^{+}$. The same cell, however, was insensitive to external $\mathrm{Cs}^{+}$during a subsequent trial performed $10 \mathrm{~min}$ after the recording shown in A1. Right panel, Diagrammatic representation of the presumed coupling-uncoupling events underlying these dynamic changes in sensitivity to potassium channel blockers. The horizontal bars in the left panel represent the duration of the application of $\mathrm{KCl}$ or $\mathrm{KCl}$ plus $\mathrm{Cs}^{+}$; voltage and time bars are shown in the left panel. B1, B2, Recording from a cell initially displaying $\mathrm{Cs}^{+}$insensitivity. Pretreatment of the cell with $\mathrm{Cs}^{+}$did not significantly affect the response to 25 $\mathrm{mm} \mathrm{KCl}$. The time course of $\mathrm{KCl}$ plus $\mathrm{Cs}^{+}$washout differs because of a slower perfusion rate and does not reflect any change induced by the drug. $B 2$, Recording from the same cell $30 \mathrm{~min}$ later. Note that although the response to high $\mathrm{K}^{+}$was virtually identical, pretreatment with the potassium channel blocker largely prevented the depolarization induced by $\mathrm{KCl}$.

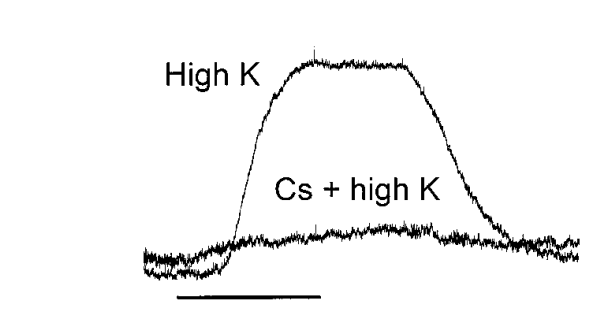

A1 INTERPRETATION

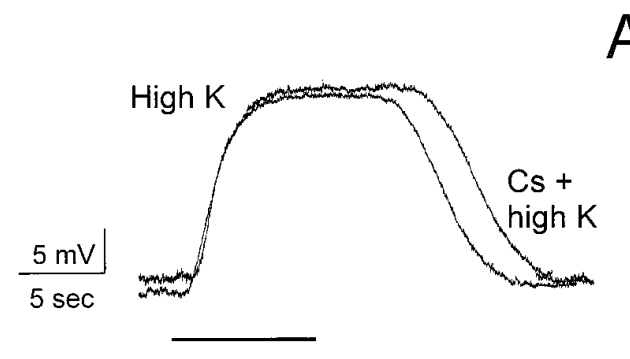

A2

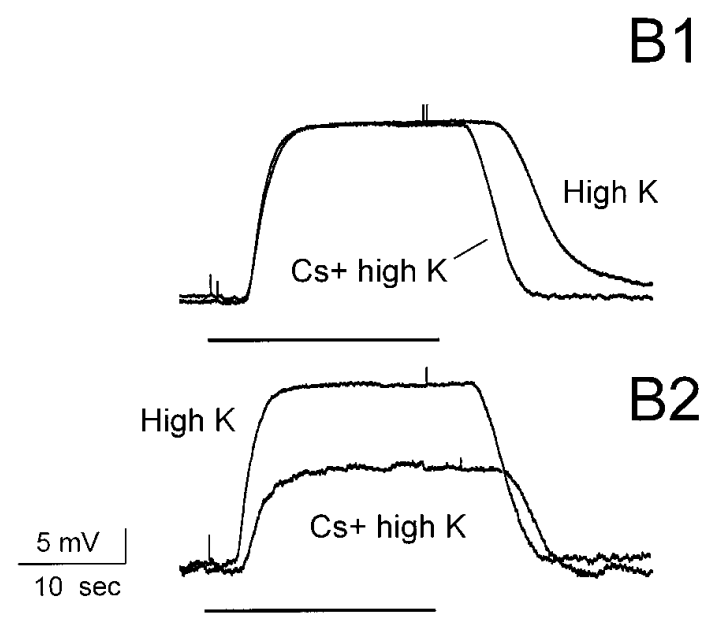

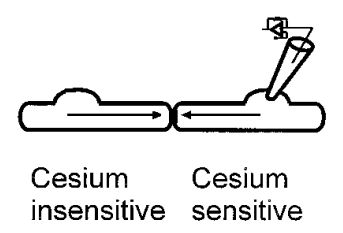
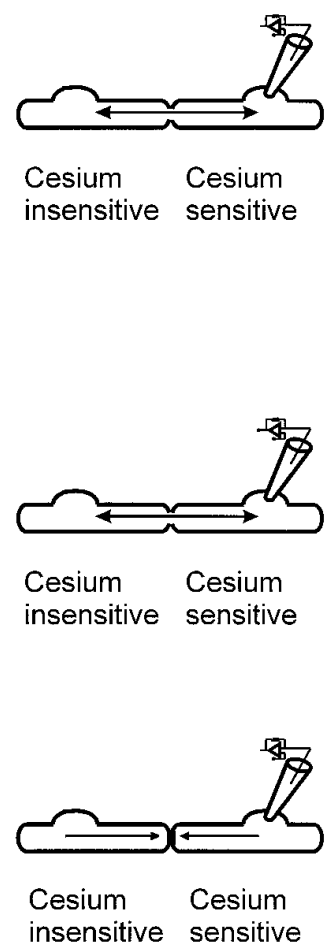

attempted to elucidate possible experimental pitfalls that may cause this apparently anomalous behavior. We thus compared results obtained with an "invasive" variation of the patch clamp (the whole-cell recording technique) with its more recent implementation, "perforated" recordings (Rhee et al., 1994). RMP heterogeneity was not caused by injury or recording technique, morphology, differentiation or proliferation, time in culture, expression of $\mathrm{Na}^{+}$or $\mathrm{K}_{(\text {ATP) }}$ channels, or lack of $\mathrm{Na}^{+} / 2 \mathrm{HCO}_{3}^{-}$co-transporter activity. We conclude that variable RMPs are intrinsic to glia and propose that this variability may potentially play an important role in determining astrocyte physiology (Fig. 11).

\section{Mechanisms involved in RMP regulation}

Although it is safe to assume that cells with extremely negative resting potentials (around $E_{\mathrm{K}}$ ) may be primarily regulating RMP by expression of large potassium currents, the question of the electrophysiological correlates of depolarized but stable RMPs remains unanswered. Several other mechanisms may explain the depolarized RMPs found in many of the cells tested. First, cortical astrocytes have been shown to express an inward, h-type current $\left(I_{\text {ha }}\right)$ that, if present, will depolarize these cells above $E_{\mathrm{K}}$ (Guatteo et al., 1996). Although $I_{\text {ha }}$ may cause a slight depolarization from $E_{\mathrm{K}}$, this ion current mechanism alone cannot explain the more depolarized RMPs recorded in our study. In fact, because of intrinsic ion channel properties, $I_{\text {ha }}$ is turned off at potentials positive to -60 to $-70 \mathrm{mV}$ and therefore is unlikely to contribute significantly at greater potentials. In agreement with this hypothesis is the finding that application of specific $I_{\text {ha }}$ blockers causes only modest $(<-10 \mathrm{mV})$ changes in astrocyte resting membrane potential (E. Guatteo and D. Janigro, unpublished observation).

$\mathrm{Na}^{+}$currents may also cause a tonic depolarization of glia. Experiments with $\mathrm{Na}^{+}$removal have been performed on spinal cord astrocytes (Ransom et al., 1996), but the interpretation of results was complicated by the intrinsic sensitivity of glial potassium channels to $\left[\mathrm{Na}^{+}\right]_{\text {out }}$. We similarly found that $\mathrm{Na}^{+}$substitution resulted in a depolarization of cells (data not shown). However, this depolarization was associated with an increase in membrane resistance, likely attributable to low $\mathrm{Na}_{\mathrm{o}}$ antagonism of inwardly rectifying potassium channels. It is thus unlikely that "background" $\mathrm{Na}^{+}$currents are responsible for the more depolarized RMP found in many neocortical astrocytes.

Astrocytes have been shown to express chloride channels and transporters (Kettenmann, 1990; Kimelberg, 1990), but a significant contribution of $\mathrm{I}_{\mathrm{C} 1}$ to RMP variability seems unlikely, because no differences were found between RMPs measured with low $\left[\mathrm{Cl}^{-}\right]_{\mathrm{I}}$ (as for whole-cell recordings) or by preserving physiological $\left[\mathrm{Cl}^{-}\right]_{\mathrm{I}}$ (during gramicidin-perforated measurements). Furthermore, the RMP values reported herein do not signifi- 

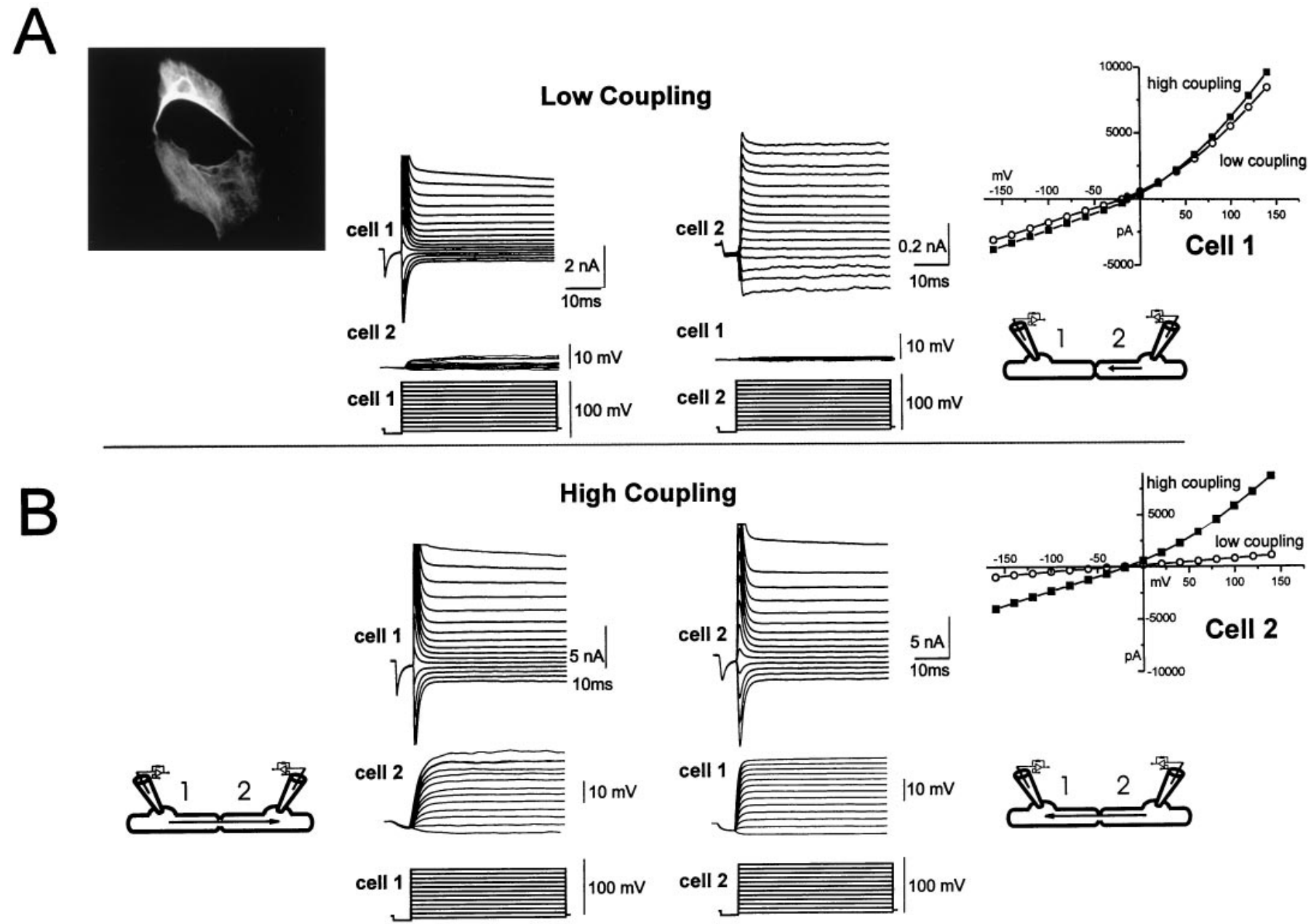

\section{Low Coupling}
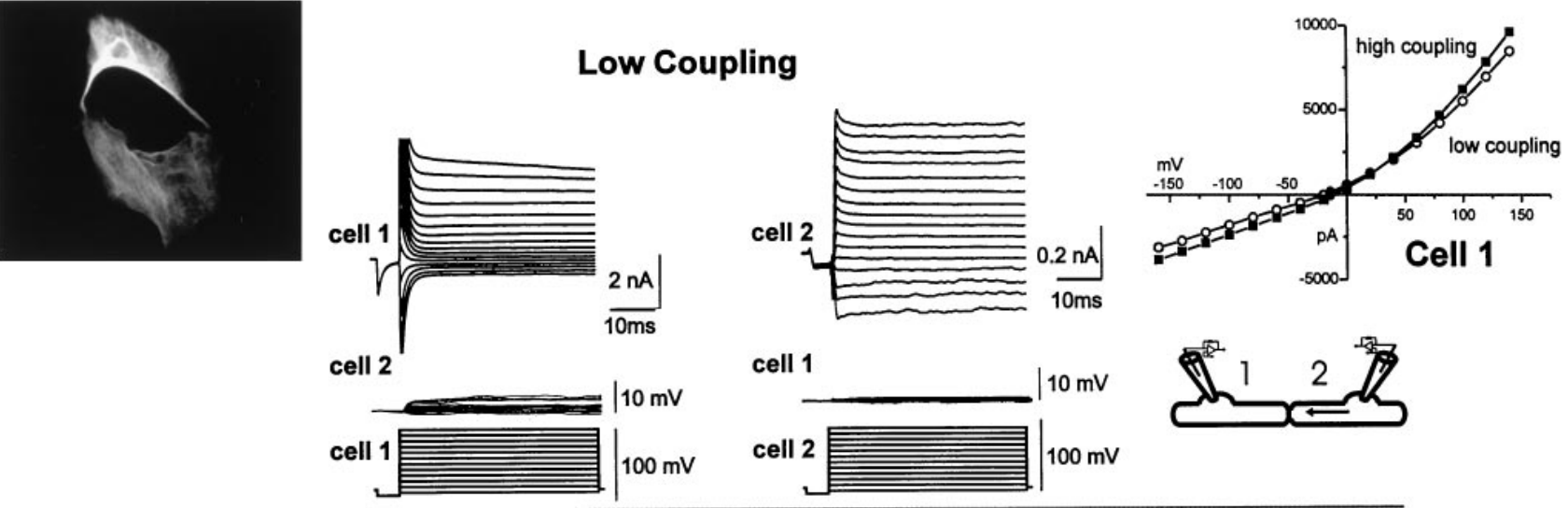

Figure 9. Intercellular coupling between astrocyte pairs is dynamic and variable. Over the course of prolonged recordings, the degree of junctional coupling between a pair of cells increased (or decreased) spontaneously, resulting in variable voltage-clamp recordings. Recording from a pair of cultured cells at a time of limited intercellular coupling (low coupling) is shown; Cell 1 had four times the total current of Cell 2 and was characterized by outward-going rectification (see $I-V$ plot in right panel, open circles); Cell 2, in contrast, displayed a modest inward rectification (inset in bottom panel). After 30 min of recording $(B)$, the cell pair spontaneously became highly coupled (high coupling). At this time, the $I-V$ profile recorded from both Cell 1 and Cell 2 was identical and increased in comparison to the recording from either cell at a time of low coupling. The high coupling recording represented a summated $I-V$ profile of the contributions of the two cells. Thus, the electrophysiological profile recorded at a given time from an individual astrocyte was dependent on the degree of intercellular coupling of that cell. Note that under conditions of low coupling, voltage clamps in Cell 1 (or Cell 2) were not capable of causing significant responses in Cell 2 (or Cell 1, bottom traces in top panel). The diagrams represent the graphic representation of our interpretation of the results. The arrow connotes the amount (and direction) of coupling at different stages during this recording. The voltage-clamp protocols used to construct the $I-V$ curves were preceded by a brief step to $-90 \mathrm{mV}$ used to measure cell capacitance. Photographic inset in $A$, Typical appearance of isolated pairs of GFAP ${ }^{+}$cells used for this study.

cantly differ from those obtained with $\mathrm{KCl}$-filled pipettes (Guatteo et al., 1996).

\section{Role of intercellular coupling in astrocyte physiology}

Intercellular coupling between astrocyte pairs was dynamic and variable. Over the course of prolonged recordings, coupling between cells could increase or decrease spontaneously, resulting in variable voltage-clamp recordings. Hence, the electrophysiological profile recorded at a given time from an individual astrocyte was dependent on the degree of intercellular coupling of that cell.

Astrocytic electrophysiological recordings are complicated by gap junctional sensitivity to $\mathrm{pH}$, calcium, and ATP. Cells maintained in HEPES-buffered solution have a more acidic $\mathrm{pH}_{\mathrm{i}}$ than those kept in $\mathrm{CO}_{2} / \mathrm{HCO}_{3}^{-} \mathrm{HCO}$-buffered solution (Rose and Ransom, 1996), a condition that favors uncoupling. Similarly, gap junctions are sensitive to changes in $\left[\mathrm{Ca}^{2+}\right]_{\mathrm{i}}$ (Giaume and $\mathrm{Mc}$ -
Carthy, 1996). Because dynamic changes in $\left[\mathrm{Ca}^{2+}\right]_{i}$ occur in astrocytes (Finkbeiner, 1992), these changes may result in timedependent variation of intercellular coupling. Gap junctions are closed at low concentrations of ATP (Vera et al., 1997); thus recordings with $0 \mathrm{mM}[\mathrm{ATP}]_{\text {pipette }}$ are likely to restrict the number of cells electrically accessible.

Our results contribute to the seemingly unsolvable paradox of electrotonically coupled cells characterized by different resting membrane potentials. A possible resolution of this apparent inconsistency depends on the extended topography of the glial syncytium. Thus, during electrophysiological investigations from an individual cell coupled to multiple glia, the recording pipette will sample the mean of the electrical properties of these cells, weighted by the electrotonic distance from the sources. We also found spontaneous and dramatic changes in cell-to-cell coupling. Differ- 


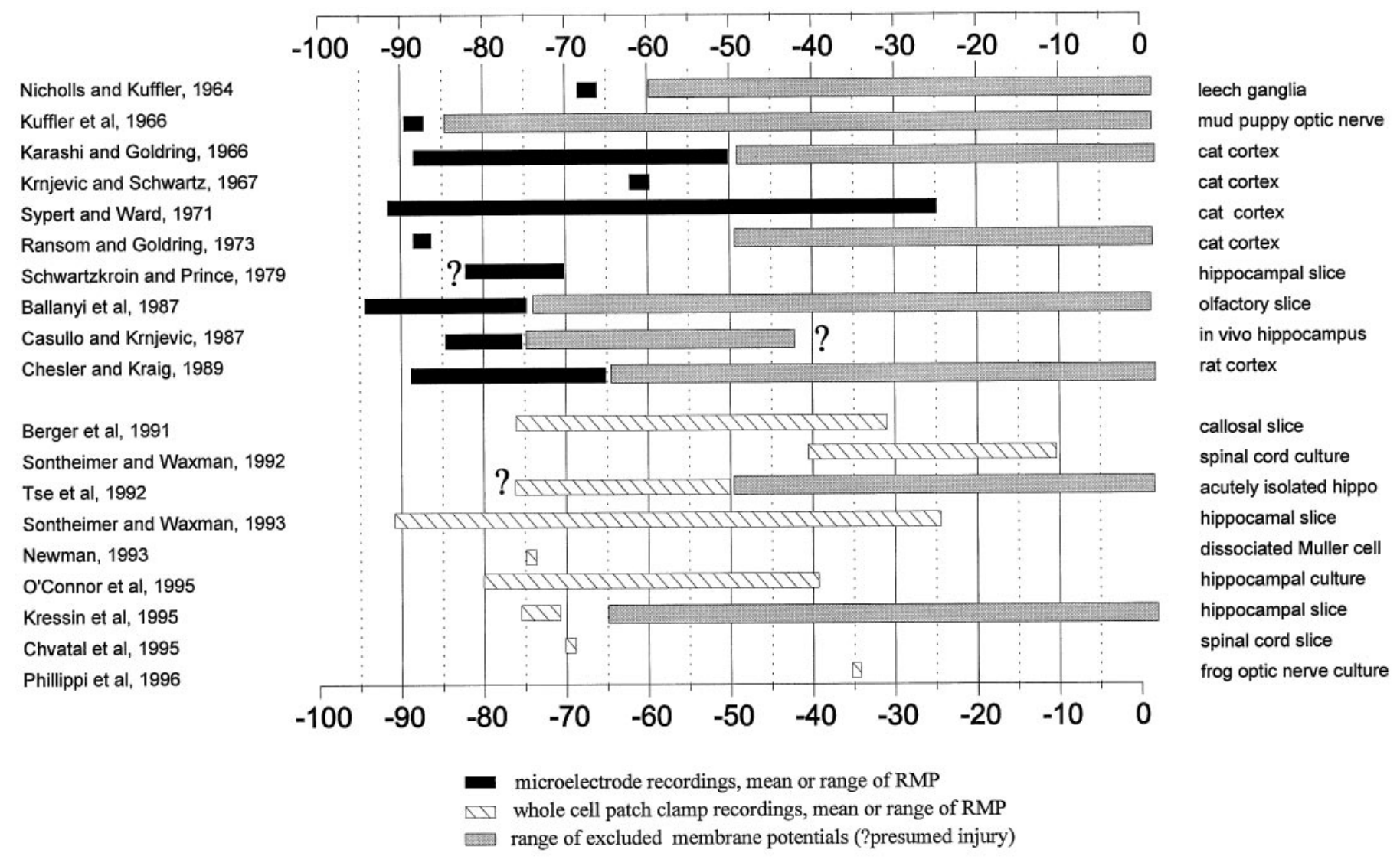

Figure 10. Resting membrane potential values reported for CNS astrocytes. The bar graph illustrates the techniques used (microelectrode vs patch clamp, dark and hatched bars) and the ranges of exclusion criteria used (gray bars) by various investigators. Wide dark and hatched bars represent the range of RMPs reported; narrow dark and hatched bars are shown when only a mean value of RMP was given. The left column lists the authors and years of the reports; the right column refers to the cell preparation and species used. If the animal preparation is not listed, a rodent model was used. Question marks are present when information presented in the study was insufficient to determine either RMP range or exclusion factors fully.

ent "electrotonic configurations" revealed segregated ionic currents, unmasking clusters of inward- or outward-rectifying cells. The combination of dynamic changes in the electrotonic properties of syncytia, together with the segregation of ion currents, are the bases for a theoretical framework to understanding the electrical substrates of heterogeneous expression of RMP in glia.

\section{Relevance to $\mathrm{K}^{+}$uptake mechanisms in CNS glia}

The exact mechanism of glial buffering of extracellular potassium has been understood only in the retina (Newman, 1995). In this region of the CNS, Newman demonstrated that potassium "siphoning" occurs by virtue of high $\mathrm{K}^{+}$conductance sites located in the plexiform layers and in the end foot of Muller cells. In contrast, the intermediate region is relatively devoid of potassium channels. As a result, spatial buffering will be directed toward regions where appropriate homeostatic mechanisms are present (such as blood vessels). Interestingly, retinal Muller cells are among the few glial cells that do not express gap junctions (Ransom, 1995). Thus, electrotonic coupling does not play a role in retinal potassium homeostasis. Because of the relatively limited topographic extension, and owing to the precise layering of principal and accessory cells of the retina itself, this unicellular mechanism seems to be sufficient to move excess potassium from its site of accumulation.

The morphological and synaptic complexity of the gray matter, together with the variable morphology of CNS glia, predict that such a simple mechanism may be insufficient to "concentration clamp" $\left[\mathrm{K}^{+}\right]_{\text {out }}$ below unacceptably high levels known to affect neuronal function. The range of potassium oscillations compatible with normal synaptic function seems to be limited to a few millimolar (Largo et al., 1996; Janigro et al., 1997a), but nevertheless significant accumulations of $\left[\mathrm{K}^{+}\right]_{\text {out }}$ can be rapidly buffered (Lux et al., 1986; Ballanyi et al., 1987). The events regulating

Figure 11. Diagrammatic representation of the proposed mechanism underlying transcellular potassium movements across cortical astrocytes (see text). Only two cells of the syncytium are shown, together with the equivalent electrical circuit showing the resistive pathways involved in the transfer of extracellular potassium from the extracellular space close to Cell 1 to Cell 2; the final step implies restitution of potassium to the extracellular space, but other mechanisms, such as backward diffusion and/or passage across the blood-brain barrier, may act in conjunction with spatial buffering (Janigro et al., 1994). Under resting conditions, both cells are bathed in similar $\left[\mathrm{K}^{+}\right]_{\text {out }}$, and Cell 1 is characterized by a resting potential close to $E_{\mathrm{K}}$ by virtue of its high potassium permeability. Cell 2 is similarly sensitive to changes in $E_{\mathrm{K}}$ but has a more depolarized resting membrane potential. Under these "resting" conditions, gap junctions are kept closed because of a relatively acidic $\mathrm{pH}_{\mathrm{i}}$ (Rose and Ransom, 1996). 1, Increases in [K $\left.{ }^{+}\right]_{\text {out }}$ in proximity to Cell 1 cause potassium influx into Cell 1; during this accumulation process, cell depolarization will occur because of the (Figure legend continues) 


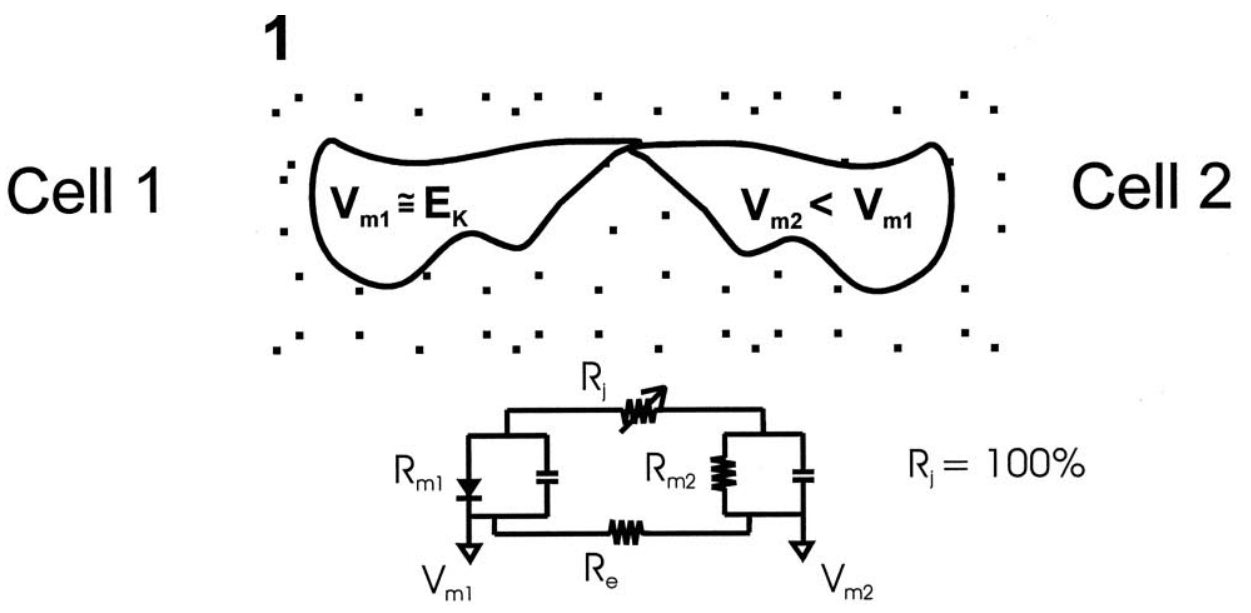

\section{2}

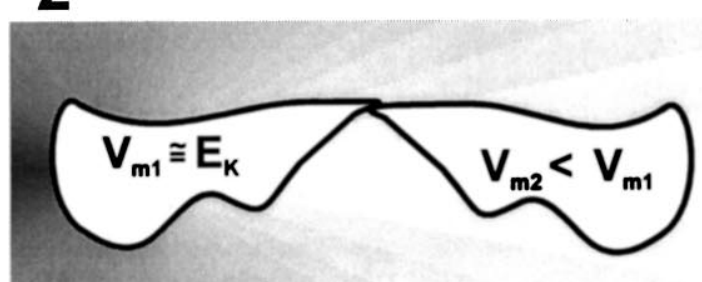

3

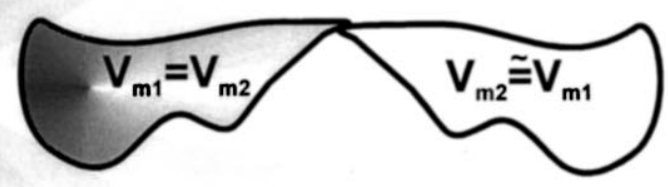

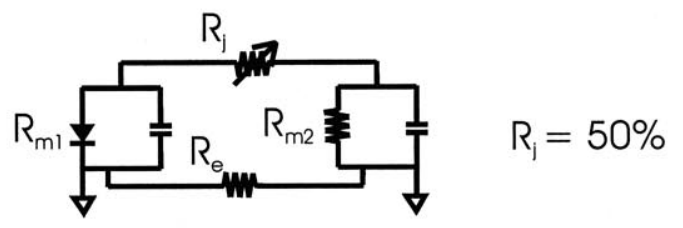
2) $\Delta V_{m l}=I_{k} R_{m l}$
2) $\Delta \mathrm{V}_{\mathrm{m} 2}$
3) $V_{m l}=E_{k}$
3) $V_{m 2} \cong V_{m 1}$

\section{4}

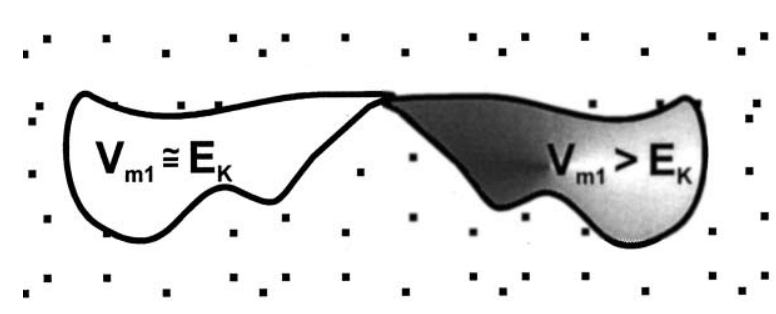

5

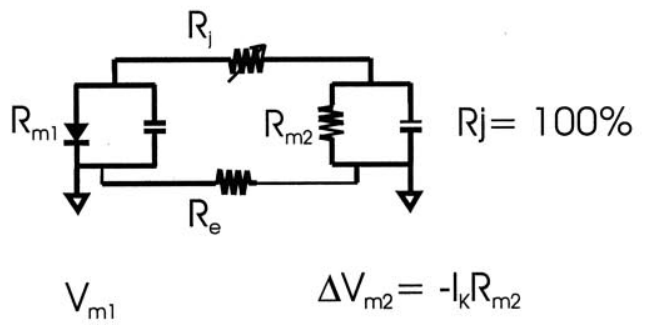

sudden shift in $E_{\mathrm{K}}$. 2, Escape of intracellular potassium in this cell cannot occur because of the exclusive presence of potassium currents characterized by inward-going rectification; furthermore, electrochemical communication with Cell 2 is precluded by the low conductance of gap junctions. As a result, a net increase in intracellular potassium sufficient to depolarize the cell occurs (3). This results in depolarization-induced alkalization (DIA) (Pappas and Ransom, 1994), subsequent opening of gap junctions, and transport of potassium to Cell 2 (4). Finally, outflow of $\mathrm{K}^{+}$occurs from Cell 2 (5). $R_{j}$, Junctional resistance ( $100 \%$ at steady state, $50 \%$ decrease after DIA); $R_{e}$, resistance of the extracellular fluid. 
potassium transport in gray matter remain, however, largely a matter of speculation. Our results shed some light on the possible mechanisms involved. First, we have demonstrated that dynamic changes in cell-to-cell coupling occur in the absence of any exogenous stimulus. These apparently untriggered reorganizations of cellular coupling may be attributable to intracellular ionic shifts that cannot be effectively controlled during patch-clamp experiments, particularly during perforated recordings. We have shown that uncoupling of cells unmasks what appears to be a segregated localization of inward- or outward-rectifying currents. This, in addition to the bimodal distribution of cortical glial RMPs, prompted us to develop a model for potassium transport across the glial syncytium (Fig. 11).

This qualitative model is based on two theoretical and experimentally tested assumptions: (1) based on observations that, during recordings from morphologically coupled cells, one cell was characterized by a resting membrane potential more negative (by 5-30 mV) than its neighbor, we assumed that more depolarized cells are coupled to cells characterized by a more negative resting membrane potential; and (2) given that basal intracellular $\mathrm{pH}$ favors gap junction closure, we hypothesized that, at rest, these glia are weakly coupled. Events occurring after neuronal activity facilitate gap junction openings (Marrero and Orkand, 1996). We thus incorporated in the model a stimulus (or $\left.\left[\mathrm{K}^{+}\right]_{\text {out }}\right)$-induced increase in intercellular $\mathrm{K}^{+}$mobility. One aspect of our working hypothesis rests on the fact that cells in which significant (and early) potassium accumulation occurs (Fig. 11, Cell 1) are characterized by selective expression of inwardly rectifying potassium channels, whereas cells adapted for potassium release (Fig. 11, Cell 2) selectively express more outward potassium channels. This hypothesis is supported by the recent localization of the delayed rectifier Kv1.5 potassium channel to astrocytic end foot processes surrounding the microvasculature in the hippocampus (Roy et al., 1996), a location ideally situated for potassium efflux. Further evidence awaits the development of specific tools to morphologically and functionally study potassium channels in astrocytes in situ.

\section{Conclusions}

In conclusion, we have shown that both cultured and hippocampal slice astrocytes are characterized by a wide range of resting potentials. More depolarized cells were not injured glia, and several chemical and developmental factors have been ruled out as possible determinants of astrocytic RMP. We have also shown that $\mathrm{Na}^{+} / 2 \mathrm{HCO}_{3}^{-}$co-transporters and $\mathrm{K}_{(\mathrm{ATP})}$ channels play little or no role in the steady-state regulation of glial RMP. In addition, we have studied the effects of intercellular coupling on glial cell physiological properties with particular emphasis on mechanisms involved in clearance and transcellular transport of potassium. We describe dynamic coupling between cultured and hippocampal slice glia and differential recorded pharmacological sensitivity of cultured astrocytes, likely as a result of changes in intercellular coupling. We propose that spatial buffering may be facilitated by heterogeneous mechanisms controlling glial resting membrane potential in combination with dynamic changes in intercellular coupling.

\section{REFERENCES}

Alger BE, McCarren M, Fisher RS (1983) On the possibility of simultaneously recording from two cells with a single microelectrode in the hippocampal slice. Brain Res 270:137-141.

Artola A, Brocher S, Singer W (1990) Different voltage-dependent thresholds for inducing long-term depression and long-term potentiation in slices of rat visual cortex. Nature 347:69-72.

Ballanyi K, Grafe P, Bruggencate GT (1987) Ion activities and potassium uptake mechanisms of glial cells of guinea-pig olfactory cortex slices. J Physiol (Lond) 382:159-174.

Barres BA, Chun LLY, Corey DP (1989) Calcium current in cortical astrocytes: induction by cAMP and neurotransmitters and permissive effect of serum factors. J Neurosci 9:3169-3175.

Barres BA, Chun LLY, Corey DP (1990) Ion channels in vertebrate glia. Annu Rev Neurosci 13:441-474.

Berger T, Schnitzer J, Kettenmann H (1991) Developmental changes in the membrane current pattern, $\mathrm{K}^{+}$buffer capacity, and morphology of glial cells in the corpus callosum slice. J Neurosci 11:3008-3024.

Black JA, Sontheimer H, Waxman SG (1993) Spinal cord astrocytes in vitro: phenotypic diversity and sodium channel immunoreactivity. Glia 7:272-285.

Bordey A, Sontheimer H (1997) Post-natal development of ionic currents in rat hippocampal astrocytes in situ, J Neurophysiol, in press.

Casullo J, Krnjevic K (1987) Glial potentials in hippocampus. Can J Physiol Pharmacol 65:847-855.

Chesler M, Kraig RP (1989) Intracellular $\mathrm{pH}$ transients of mammalian astrocytes. J Neurosci 9:2011-2019.

Chvatal A, Pastor A, Mauch M, Sykov'a E, Kettenmann H (1995) Distinct populations of identified glial cells in the developing rat spinal cord slice: ion channel properties and cell morphology. Eur J Neurosci $7: 129-142$.

Dermietzel R, Hertberg EL, Kessler JA, Spray DC (1991) Gap junctions between cultured astrocytes: immunocytochemical, molecular, and electrophysiological analysis. J Neurosci 11:1421-1432.

Erdemli G, Krnjevic K (1994) Guanosine diphosphate is required for activation of a glyburide, ATP and cromakalim-sensitive outward current in rat hippocampal neurons. NeuroReport 5:1362-1364.

Finkbeiner S (1992) Calcium waves in astrocytes-filling in the gaps. Neuron 8:1101-1108.

Giaume C, McCarthy KD (1996) Control of gap-junctional communication in astrocytic networks. Trends Neurosci 19:319-325.

Giaume C, Fromaget C, el Aoumari A, Cordier J, Glowinski J, Gros D (1991) Gap junctions in cultured astrocytes: single-channel currents and characterization of channel-forming protein. Neuron 6:133-143.

Guatteo E, Stanness KA, Janigro D (1996) Hyperpolarization-activated currents in cultured rat cortical and spinal cord astrocytes. Glia 16:196-209.

Guizzetti M, Costa P, Peters J, Costa LG (1996) Acetylcholine as a mitogen: muscarinic receptor-mediated proliferation of rat astrocytes and human astrocytoma cells. Eur J Pharmacol 297:265-273.

Janigro D, Schwartzkroin PA (1988) Effects of GABA and baclofen on pyramidal cells in the developing rabbit hippocampus: an "in vitro" study. Brain Res 469:171-184.

Janigro D, West GA, Gordon EL, Winn HR (1993) ATP-sensitive K ${ }^{+}$ channels in rat aorta and brain microvascular endothelial cells. Am J Physiol 265:812-821.

Janigro D, West GA, Nguyen T, Winn HR (1994) Regulation of bloodbrain barrier endothelial cells by nitric oxide. Circ Res 75:528-538.

Janigro D, Gasparini S, D'Ambrosio R, McKhann II GM, DiFrancesco D (1997a) Reduction of $\mathrm{K}^{+}$uptake in glia prevents LTD maintenance and causes epileptiform activity. J Neurosci 17:2813-2824.

Janigro D, Nguyen T, Meno J, West GA, Winn HR (1997b) Endothelium-dependent regulation of cerebrovascular tone by extracellular and intracellular ATP. Am J Physiol 42:H878-H885.

Joyner R, Somjen GG (1973) A model simulating the hypothetical contribution of glia cells to extracellular potentials. Prog Neurobiol 1:227-237.

Karahashi Y, Goldring S (1966) Intracellular potentials from "idle" cells in cerebral cortex of cat. Electroencephalogr Clin Neurophysiol 20:600-607.

Kettenmann H (1990) Chloride channels and carriers in cultured glial cells. In: Chloride channels and carriers in nerve, muscle, and glial cells. (Alvarez-Leefmans FJ, Russel JM, eds), pp 193-208. New York: Plenum.

Kimelberg HK (1990) Chloride transport across glial cell membrane. In: Chloride channels and carriers in nerve, muscle, and glial cells (Alvarez-Leefmans FJ, Russel JM, eds), pp 159-191. New York: Plenum.

Kressin K, Kuprijanova E, Jabs R, Seifert G, Steinhauser C (1995) 
Developmental regulation of $\mathrm{Na}^{+}$and $\mathrm{K}^{+}$conductances in glial cells of mouse hippocampal brain slices. Glia 15:173-187.

Krnjevic K, Schwartz S (1967) Some properties of unresponsive cells in the cerebral cortex. Exp Brain Res 3:306-319.

Kuffler SW (1967) Neuroglial cells: physiological properties and a potassium-mediated effect of neuronal activity on the glial membrane potential. Proc R Soc Lond [Biol] 168:1-21.

Kuffler SW, Nichols JG, Orkand RK (1966) Physiological properties of glial cells in the central nervous system of amphibia. J Neurophysiol 29:768-787.

Largo C, Cuevas P, Somjen GG, Martin del Rio R, Herreras O (1996) The effect of depressing glial function in rat brain in situ on ion homeostasis, synaptic transmission, and neuron survival. J Neurosci 16:1219-1229.

Lee SH, Kim WT, Cornell Bell AH, Sontheimer H (1994) Astrocytes exhibit regional specificity in gap-junction coupling. Glia 11:315-325.

Lux HD, Heinemann U, Dietzel I (1986) Ionic changes and alterations in the size of extracellular space during epileptic activity. In: Advances in Neurology. (Delgado-Escueta AV, Ward AA, eds), pp 619-639. New York: Raven.

Marrero H, Orkand RK (1996) Nerve impulses increase glial intercellular permeability. Glia 16:285-289.

McKhann GM, D'Ambrosio R, Janigro D (1997) Potential pitfalls in the pharmacological investigation of astrocyte ion channels and gap junctions. Soc Neurosci Abstr. vol. 22.

Newman EA (1995) Glial cell regulation of extracellular potassium. In: Neuroglia. (Kettenmann H, Ransom BR, eds), pp 717-731. New York: Oxford University.

Nicholls JG, Kuffler SW (1964) Extracellular space as a pathway for exchange between blood and neurons in the CNS of the leech: ionic composition of glial cells and neurons. J Neurophysiol 27:645-671.

O'Connor ER, Sontheimer H, Ransom BR (1994) Rat hippocampal astrocytes exhibit electrogenic sodium-bicarbonate co-transport. J Neurophysiol 72:2580-2589.

Pappas CA, Ransom BR (1994) Depolarization-induced alkalinization (DIA) in rat hippocampal astrocytes. J Neurophysiol 72:2816-2826.

Paulson OB, Newman EA (1987) Does the release of potassium from the endfeet regulate cerebral blood flow? Science 237:896-898.

Philippi M, Vyklicky L, Orkand RK (1996) Potassium currents in cultured glia of the frog optic nerve. Glia 17:72-82.

Raff MC, Abney ER, Cohen J, Linsday R, Noble M (1983) Two types of astrocytes in cultures of developing white matter. J Neurosci 3:1289-1300.

Ransom BR (1995) Gap junctions. In: Neuroglia. (Kettenmann H, Ransom BR, eds), pp 299-318. New York: Oxford University.
Ransom BR, Goldring S (1973a) Ionic determinants of membrane potential of cells presumed to be glia in cerebral cortex of cat. J Neurophysiol 36:855-868.

Ransom BR, Goldring S (1973b) Slow depolarization in cells presumed to be glia in cerebral cortex of cat. J Neurophysiol 36:869-878.

Ransom BR, Goldring S (1973c) Slow hyperpolarization in cells presumed to be glia in cerebral cortex of cat. J Neurophysiol 36:879-892.

Ransom CB, Sontheimer H (1995) Biophysical and pharmacological characterization of inwardly rectifying potassium currents in rat spinal cord astrocytes. J Neurophysiol 73:333-346.

Ransom CB, Sontheimer H, Janigro D (1996) Astrocytic inwardlyrectifying potassium currents are dependent on extracellular sodium ions. J Neurophysiol 76:626-630.

Rhee J, Ebihara S, Akaike N (1994) Gramicidin perforated patchclamp technique reveals glycine-gated outward chloride currents in dissociated nucleus solitarii neurons of the rat. J Neurophysiol 72:1103-1108.

Rose CR, Ransom BR (1996) Mechanism of $\mathrm{H}^{+}$and $\mathrm{Na}^{+}$changes induced by glutamate, kainate, and D-Aspartate in rat hippocampal astrocytes. J Neurosci 16:5393-5404.

Roy ML, Saal D, Perney T, Sontheimer H, Waxman SG, Kaczmarek LK (1996) Manipulation of the delayed rectifier Kv1.5 potassium channel in glial cells by antisense oligonucleotides. Glia 18:177-184.

Schwartzkroin PA, Prince DA (1979) Recordings from presumed glial cells in the hippocampal slice. Brain Res 161:533-538.

Sontheimer H (1994) Voltage-dependent ion channels in glial cells. Glia 11:156-172.

Sontheimer H, Waxman SG (1993) Expression of voltage-activated ion channels by astrocytes and oligodendrocytes in the hippocampal slice. J Neurophysiol 70:1863-1873.

Sontheimer H, Black JA, Ransom BR, Waxman SG (1992) Ion channels in spinal cord astrocytes in vitro I. Transient expression of high levels of $\mathrm{Na}+$ and $\mathrm{K}+$ channels. J Neurophysiol 68:985-1000.

Steinhauser C (1993) Electrophysiologic characteristics of glial cells. Hippocampus 3:113-124.

Sypert GW, Ward AA (1971) Unidentified neuroglia potentials during propagated seizures in neocortex. Exp Neurol 33:239-255.

Tse FW, Fraser DD, Duffy S, MacVicar BA (1992) Voltage-activated $\mathrm{K}^{+}$currents in acutely isolated hippocampal astrocytes. J Neurosci 12:1781-1788.

Vera B, Sanchez Abarca LI, Bolanos JP, Medina JM (1997) Inhibition of astrocyte gap junctional communication by ATP depletion is reversed by calcium sequestration. FEBS Lett 392:225-228. 